\title{
Sequence Mutations of Genes Pertaining to Malignancy in Cancer
}

\author{
Nardnisa Sintupisut* and Chen-Hsiang Yeang \\ Academia Sinica
}

\begin{abstract}
Cancer is a complex disease where various types of molecular aberrations drive the development and progression of malignancies. Among the diverse molecular aberrations, inherited and somatic mutations on DNA sequences are considered as major drivers for oncogenesis. The complexity of somatic alterations is revealed from large-scale investigations of cancer genomes and robust methods for interring the function of genes. In this review, we will describe sequence mutations of several cancer-related genes and discuss their functional implications in cancer. In addition, we will introduce the on-line resources for accessing and analyzing sequence mutations in cancer. We will also provide an overview of the statistical and computational approaches and future prospects to conduct comprehensive analyses of the somatic alterations in cancer genomes.
\end{abstract}

Key words: Cancer, cancer databases, mutations.

\section{Introduction}

Cancer cells harbor a large number of molecular aberrations. At DNA levels the sequence contents, copy numbers and epigenetic states of many genes and non-coding regions undergo abnormal changes. At RNA levels many mRNAs and microRNAs are differentially expressed or possess abnormal splice forms. At protein levels the expressions, activities and functions of proteins may also change. These alterations perturb the gene regulatory networks and thus empower cells with capacities for malignancy such as perpetual replication, abrogation of apoptosis, potential for metastasis and drug resistance. Information about these aberrations provides a molecular basis to understand the mechanisms of tumorigenesis and develop prognosis and treatment technologies of cancer.

Among the various molecular aberrations, mutations on DNA sequences are considered as the most upstream and major driving events for oncogenesis. Base

${ }^{*}$ Corresponding author. 
substitutions may alter the structures and functions of proteins, introduce early stop codons in RNA synthesis, or affect transcription factor bindings on promoters. In addition, insertions and deletions of DNA fragments may add/remove amino acid residues of encoded proteins, change reading frames and disrupt RNA synthesis, as well as amplify or delete transcription factor binding sites (see definition of mutation types from Figure 1). Decades of cancer studies prior to the post-genomic era have accumulated substantial knowledge regarding the sequence mutations of well-known oncogenes and tumor suppressors. The functional and mechanistic consequences of sequence mutations on a few genes such as TP53 and TP16 are thoroughly documented. However, the biological implications of most sequence mutations or variations remain unclear. These variations include the genomic alterations that cause or promote cancers (drivers) and the alterations that are present in the cancer genomes but do not contribute to carcinogenesis (passengers) (Davies et al., 2005). Separation of the driver mutations responsible for clinical phenotypes from the vast number of passenger mutations is a leading question of cancer genomics today.

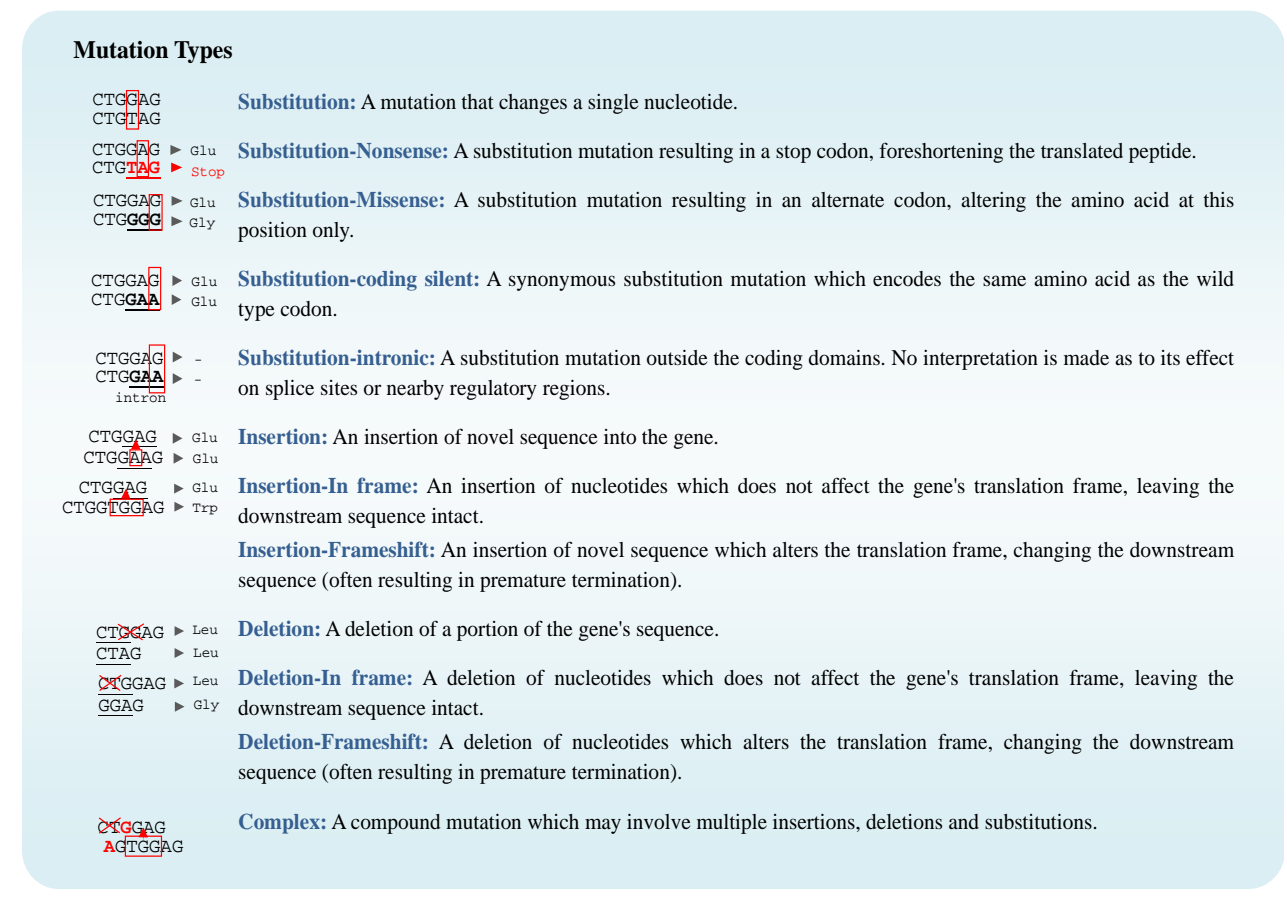

Figure 1: Mutation type and definition

\section{Somatic Mutations and Their Implications in Cancer}

As a central driving cause of tumorigenesis, somatic mutations have been 
broadly documented. Alterations on protein coding or regulatory regions of the genome potentially disturb or enhance the normal functions of a gene, and these changes may be transmitted to descendants through a lineage of reproductive cells (Knudso, 2001). Some genetic alterations are confined to local regions or single genes. These include missense or nonsense base substitutes, insertions and deletions that lead to frameshift (Lewin, 2004). Other alterations may affect large genomic regions such as rearranged chromosomal segments and copy number variations (Edmunds, 2008).

In cancer, somatic mutations can arise in the genomes of dividing cells during DNA replication. Genetic modifications exhibit diverse patterns in different cancers. Some cancer genomes contain more than 100,000 mutations, whereas the others may carry less than 1,000 mutations (Greenman et al., 2007; Wood et al., 2007; Sjöblom et al., 2006; Stephens et al., 2005). The functions of most of these mutated genes possess one or multiple "hallmarks" of cancer (Hanahan and Weinberg, 2011). The hallmarks include sustaining proliferative signaling, evading growth suppressors, resisting cell death, enabling replicative immortality, inducing angiogenesis, and activating invasion and metastasis. First, cancer cells constantly fire proliferative signals, while normal cells carefully control the production and release of growth-promoting signals through the cell cycle. Progression from one phase to the next phase of the cycle is controlled by a series of checkpoints. In cancer cells, the checkpoints are typically defective. Abnormal cell divisions can further destabilize cancer genomes and facilitate somatic mutations. Unrepaired/mutated DNA can enter cell cycles and result in an incorrect segregation of their chromosomes. The dysregulated proliferative signals are conveyed by growth factors, emitted via branched intracellular signaling pathways, and lead to malignancy. Second, cancer cells typically block or suppress anti-growth signals through cell cycle regulation. In normal cells, growth factor signals are antagonized by cellular conditions such as cell sizes, DNA damage, and deficiency of nutrients or oxygen. In cancer cells, some of the tumor suppressor genes controlling anti-growth signals are mutated and thus dysfunctioning. Third, as another line of self-defense, abnormally dividing cells often trigger the mechanisms of programmed cell death (apoptosis). However, cancer cells typically harbor mutations on key genes of these mechanisms to evade apoptosis. Fourth, abnormally dividing cells escaping apoptosis still cannot replicate perpetually, as cell divisions will shorten the terminal ends of chromosomes (telomeres) and make the descendant cells become "aged". Cancer cells, however, are often capable of maintaining telomeres and thus preventing cell ageing. In addition to alterations within cancer cells, processes pertaining to interactions between cancer cells and the surrounding environment are also compromised. Some of the prominent processes altered include formation of new blood vessels (angiogenesis) to supply tumors with oxygen and nutrient, invasion to the surrounding tissue and migra- 
tion to remote sites (metastasis), prevention of attack from the immune system, and chronic inflammation.

There are several ways to investigate the patterns of somatic mutations in distinct cancers. Some studies identified these patterns by estimating the rates of genomic rearrangement. For example, in colorectal and endometrial cancer, rates of single nucleotide changes and small insertions and/or deletions at polynucleotide fragments of MLH1 and MSH2 show increased values which can clearly define neoplastic changes (Vogelstein et al., 1988; Lengauer et al., 1998). Other phenotypic evidence such as erosion of telomeres can reveal mutated genes by capping the ends of chromosomes and provide an accumulation of numerous mutations with a high rate (Artandi and DePinho, 2010). However, some studies conflictingly suggested that only mutation rates of normal cells, without any phenotypic mutators, may be adequate for capturing the development in some cancers (Bodmer and Loeb, 2008; Loeb et al., 2008).

Non-synonymous (missense, nonsense or frameshift) mutations can be responsible for cancer development and progression (Edmunds, 2008; Weinberg, 2007). However, only a small fraction of them called drivers actually cause tumors. The remaining mutations in cancer genomes are likely to be neutral and are not considered as a major cause in tumorigenesis. The term passengers is used to denote this type of mutation (Greenman et al., 2007). In general, drivers compromise the process of cell maintenance by conferring a clonal growth advantage on cancer cells, but the passengers do not. Distinguishing driver from passenger mutations is a key challenge in cancer genomics for the strong implication in prognosis and treatment and the defining of functional information of most mutations (Greenman et al., 2007; Ferrer-Costa et al., 2005).

Several methods for classifying mutations as drivers or passengers are reported in Figure 1 and Table 1. The first fourteen rows of Table 1 are from Baudot et al. (2009). Since the drivers would affect protein functions, assessing the impact of mutations in conserved domains of a given protein is suggested. The prediction models based on sequences and/or protein structures were demonstrated through functionally neutral and deleterious amino acid changes (Yue et al., 2006; Torkamani and Schork, 2007; Ferrer-Costa et al., 2005). Several bioinformatics tools are used to prioritize candidate mutated genes. For instance, $\mathrm{Ng}$ and Henikoff (2003) developed SIFT (Sorting Intolerant From Tolerant) by using sequence homology between closely related protein species to measure effects of amino acid substitutions in protein-coding regions. Likewise, Clifford et al. (2004) developed the LogR.E-value algorithm to determine the difference between a wildtype and variant protein by measuring their fitness to a Pfam model. Kaminker et al. (2007b) developed CanPredict using known cancer-associated variants to build a general description of a cancer mutation. They combined SIFT, LogR.E and 
gene ontology similarity score (GOSS) to measure the characteristics of a cancer mutation and classify variants as cancer or non-cancer. Ferrer-costa et al. (2005) developed a web-based tool called pMut for the annotation of pathological mutations on proteins. However, the prevalence and characteristics of drivers and passengers are not well defined. The structure-based models confirmed the passenger mutations but did not find any predicted driver mutations. Thus, other investigations were recommended. The ratio between non-synonymous and synonymous mutation rates $\left(K_{a} / K_{s}\right.$ rates) is commonly used to quantify the strength of natural selection in molecular evolution (Greenman et al., 2007). Higher ratios can be remarked as a result of a positive selection driving oncogenesis. However, passenger mutations may have similar $K_{a} / K_{s}$ ratios to driver mutations as they may also alter protein structures. Therefore, an alternative approach calculated the differences between observed and expected frequencies of non-synonymous mutations (Wood et al., 2007; Sjöblom et al., 2006). A gene with a higher frequency of observed mutations relative to the expected frequency was expected as a driver. Another approach to identify drivers focused on large homozygous deletions (HDs) of recessive cancer genes (Bignell et al., 2010) such as CDKN2A, RB1, SMAD4, SMARCB1, MAP2K or PTEN. Yet, in addition of recessive cancer genes, HDs also appear on common fragile sites. A presence of inactivating mechanisms that occurs on fragile sites such as protein truncation have been applied to detect a number of HDs and their associated regions (Lukusa et al., 2008). However, a limitation of these methods is a requirement of very large sample size. The insufficient samples would not meet the statistical thresholds. Furthermore, these statistical criteria do not provide information about the specific alleles such as point mutations that may affect epigenetic states. For example, a decreased vulnerability of C-to- $\mathrm{T}$ transition mutations can increase an efficiency of methylation in CpG sites and lead to gene silencing (Jones and Baylin, 2002). To address this drawback, genetic information such as related pathways and/or annotation of known cancer genes have been currently incorporated in analysis (Ekins et al., 2007; Subramanian et al., 2005; Redon et al., 2006; Kaminker et al., 2007a, Aerts et al., 2006; Furney et al., 2008).

In addition, although the total number of mutations in cancers is large, only a few genes such as TP53 and RB1 may have prevalent and recurrent mutations (Soussi, 2000; Valverde et al., 2005; Forbes et al., 2011), and mutated genes may be concentrated in a small number of signaling pathways. These core pathways are essential for therapeutics and/or drug design in order to examine the target protein. In addition to the analysis of single genes, the combinatorial patterns of somatic mutations were studied through large-scale sequencing data (Yeang et al., 2008). The observations confirmed that the mutation signatures are heterogeneous in different tumor tissues. These patterns revealed the functional relations of genes in core pathways of cancer including cell cycle control, stress response, 
Table 1: The main recent high-throughput cancer genomic studies and initiatives. (The first fourteen rows are from Baudot et al., 2009, Table 1)

\begin{tabular}{|c|c|c|c|c|}
\hline Study & Gene & Tumor & Screen size & PM ID \\
\hline Bardelli et al., 2003 & $\begin{array}{l}\text { Tyrosine } \\
\text { kinase }\end{array}$ & Colon & $\begin{array}{l}138 \text { genes, } 35 \text { samples, a subset } \\
\text { in } 147 \text { additional samples }\end{array}$ & 12738854 \\
\hline Wang et al., 2004 & $\begin{array}{l}\text { Tyrosine } \\
\text { phosphatase }\end{array}$ & Colon & $\begin{array}{l}87 \text { genes, } 18 \text { samples, a subset } \\
\text { in } 157 \text { additional samples }\end{array}$ & 15155950 \\
\hline Stephens et al., 2005 & Kinase & Breast & $\begin{array}{l}518 \text { genes, } 25 \text { samples, a subset } \\
\text { in } 56 \text { additional samples }\end{array}$ & 15908952 \\
\hline Davies et al., 2005 & Kinase & Lung & $\begin{array}{l}518 \text { genes, } 33 \text { samples, a subset } \\
\text { in } 56 \text { additional samples }\end{array}$ & 16140923 \\
\hline Sjöblom et al., 2006 & All & Breast \& colon & $\begin{array}{l}\text { 13,023 genes, } 22 \text { samples, a subset } \\
\text { in } 48 \text { additional samples }\end{array}$ & 16959974 \\
\hline Greenman et al., 2007 & Kinase & 210 human cancers & 518 genes in 210 samples & 17344846 \\
\hline Wood et al., 2007 & All & Breast and colon & $\begin{array}{l}\text { 18,191 genes, } 22 \text { samples, a subset } \\
\text { in } 48 \text { additional samples }\end{array}$ & 17932254 \\
\hline Loriaux et al., 2008 & $\begin{array}{l}\text { Tyrosine } \\
\text { kinase }\end{array}$ & $\begin{array}{l}\text { Acute myeloid } \\
\text { leukaemia }\end{array}$ & 85 genes, 188 samples & 18252861 \\
\hline Tomasson et al., 2008 & $\begin{array}{l}\text { Tyrosine } \\
\text { kinase }\end{array}$ & $\begin{array}{l}\text { Acute myeloid } \\
\text { leukaemia }\end{array}$ & $\begin{array}{l}26 \text { genes, } 94 \text { samples, a subset } \\
\text { in } 94 \text { additional samples }\end{array}$ & 18270328 \\
\hline Brown et al., 2008 & $\begin{array}{l}\text { Tyrosine } \\
\text { kinase }\end{array}$ & $\begin{array}{l}\text { Chronic lymphocytic } \\
\text { leukaemia }\end{array}$ & 70 genes, 95 samples & 18754031 \\
\hline Jones et al., 2008 & All & Pancreas & 20,661 genes, 24 samples & 18772397 \\
\hline Parsons et al., 2008 & All & Glioblastoma & $\begin{array}{l}20,661 \text { genes, } 22 \text { samples, a subset } \\
\text { in } 83 \text { additional samples }\end{array}$ & 18772396 \\
\hline TCGA, 2008 & 601 genes & Glioblastoma & 601 genes, 91 samples & 18772890 \\
\hline Ding et al., 2008 & 623 genes & Lung & 623 genes, 188 samples & 18948947 \\
\hline Yeang et al., 2008 & All & 210 human cancers & $\begin{array}{l}3303 \text { genes, } 45 \text { cancer tissues, } \\
218323 \text { cancer samples and } \\
514020 \text { records from } 4138 \text { studies }\end{array}$ & 18434431 \\
\hline Bignell et al., 2010 & All & Cancer cell lines & $\begin{array}{l}746 \text { cancer cell lines with } \\
2428 \text { somatic homozygous deletions }\end{array}$ & 20164919 \\
\hline
\end{tabular}

IGF-AKT, TGF- $\beta$, WNT and RAS pathways. Their subsumption relations revealed the order of mutational events. Furthermore, the observed mutational patterns suggested new co-sequencing targets that could be applied to reveal novel patterns and/or validate the predictions from the existing patterns. These analyses are based on previous knowledge of known pathways and gene functions and provide insights into the tumorigenesis.

So far, at least $390(1.7 \%)$ of about 22,000 protein-coding genes have been reported as drivers with strong evidence (Stratton et al., 2009) (http://www.sanger. ac.uk/genetics/CGP/Census/). About $90 \%$ are somatic mutations, whereas about $20 \%$ and $10 \%$ are germline mutations and both germline and somatic mutations, respectively. Most of them were discovered by their physical locations in the genome, while a few drivers were guided by functional analysis and feasible information from the previous studies (Stratton et al., 2009). The low-resolution 
genome-wide screens and in particular cytogenetics for chromosomal translocations (Drexler et al., 1995) are the main tools to explore the locations of genetic aberrations. The cancer genes in germlines were identified by genetic linkage analysis (Antoniou and Easton, 2006) (see for example, Palmieri et al., 2002; te Velde and Pearson, 2002; Kok et al., 2005).

The functional characteristics of drivers were classified as gain- or loss-offunction mutations (Weinberg, 2007). Oncogenes are involved in cell growth and differentiation. By definition, these genes possess gain-of-function mutations or dominant effects in cancer (Stratton et al., 2009). Conversely, tumor suppressor genes are anti-oncogenes that inhibit cellular proliferation. These genes possess loss-of-function mutations or recessive effects in cancer. Most known somatically mutated cancer genes are dominant: alterations on one allele suffice to activate/ enhance the function of the protein and facilitate oncogenesis. In contrast, aberrations on both alleles of recessive genes are required to provoke proliferation by abolishing the protein function. The genes that participate in these pathways and their cascade mechanisms are summarized in Table 2.

\section{Databases of Somatic Mutations and Integrative Analyses in Can- cer Genomic Data}

The Catalog of Somatic Mutations in Cancer (COSMIC) (http://www.sanger. ac.uk/perl/genetics/CGP/cosmic) is the largest public resource for information on somatic mutations in cancer (Forbes et al., 2010). Mutational records (primarily point mutations and small-scale insertions/deletions) of human cancers are extracted from a large number of prior publications. COSMIC data is primarily web-driven, focused on providing mutation range and frequency statistics based upon a choice of gene and/or cancer phenotype. Based on v. 51 (January, 2011), COSMIC encompasses 19,001 genes screened from 580,306 samples in 2.9 million experiments and reports 167,193 mutations (Table 3). In addition to COSMIC, Wellcome Trust Sanger Institute also provides other related projects including Cancer Gene Census (CGC) (http://www.sanger.ac.uk/genetics/CGP/Census/), Genome Wide LOH and Copy Number Analysis (http://www.sanger.ac.uk/ genetics/CGP/CopyNumberMapping/), NCI-60 Cancer Cell Line Mutation Data (http://www.sanger.ac.uk/genetics/CGP/NCI60/), Cancer Cell Line Project (http://www.sanger.ac.uk/genetics/CGP/CellLines/), Genomics of Drug Sensitivity in Cancer (http://www.sanger.ac.uk/genetics/CGP/translation/). Although these projects focus on different aspects of gene mutations (see Table 4), the ultimate goal is the same: to provide comprehensive and feasible sources of human cancer genomes. In the past few years, the cancer genome sequencing studies have been substantially growing in size, in which most of candidate genes were cataloged in COSMIC. 


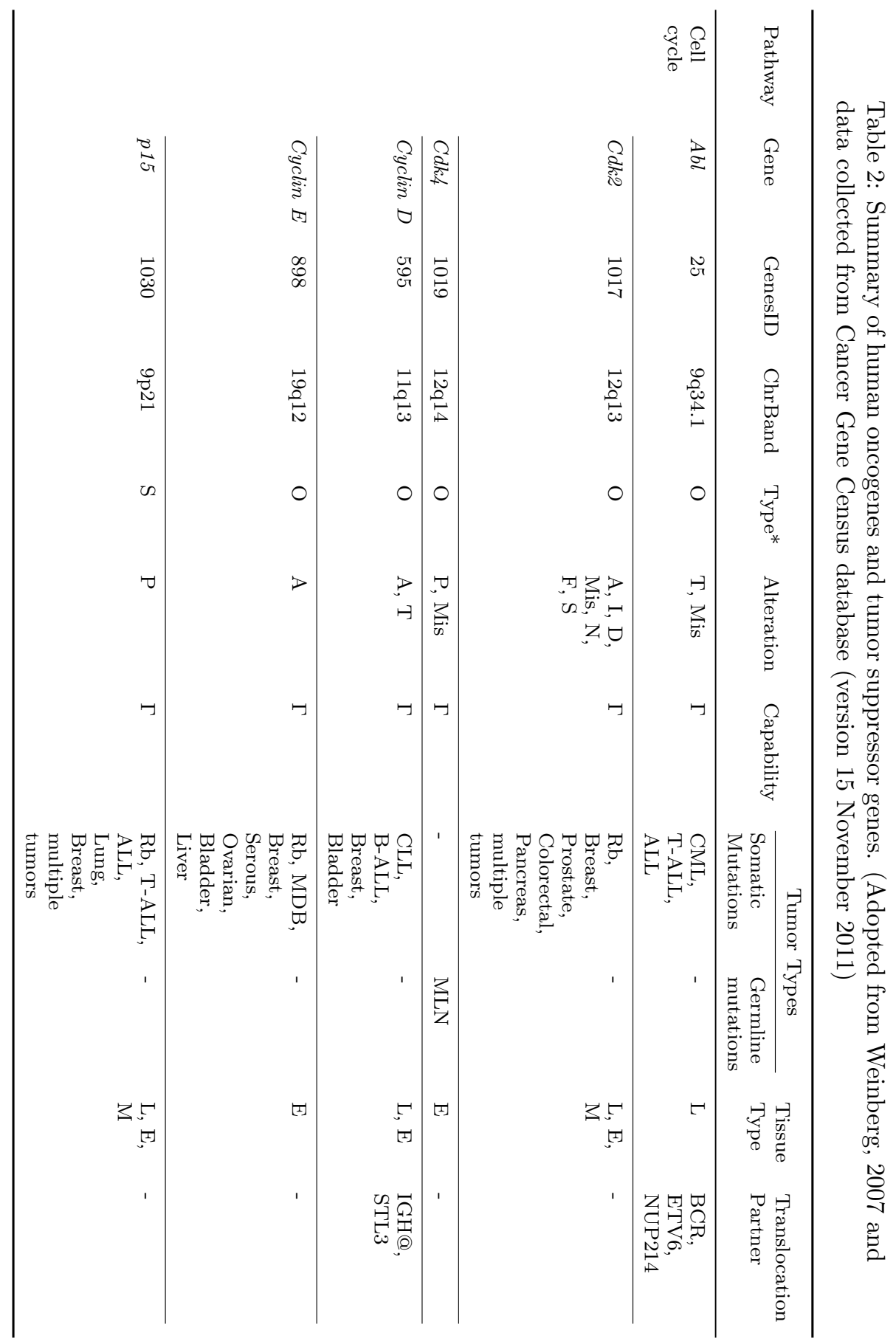




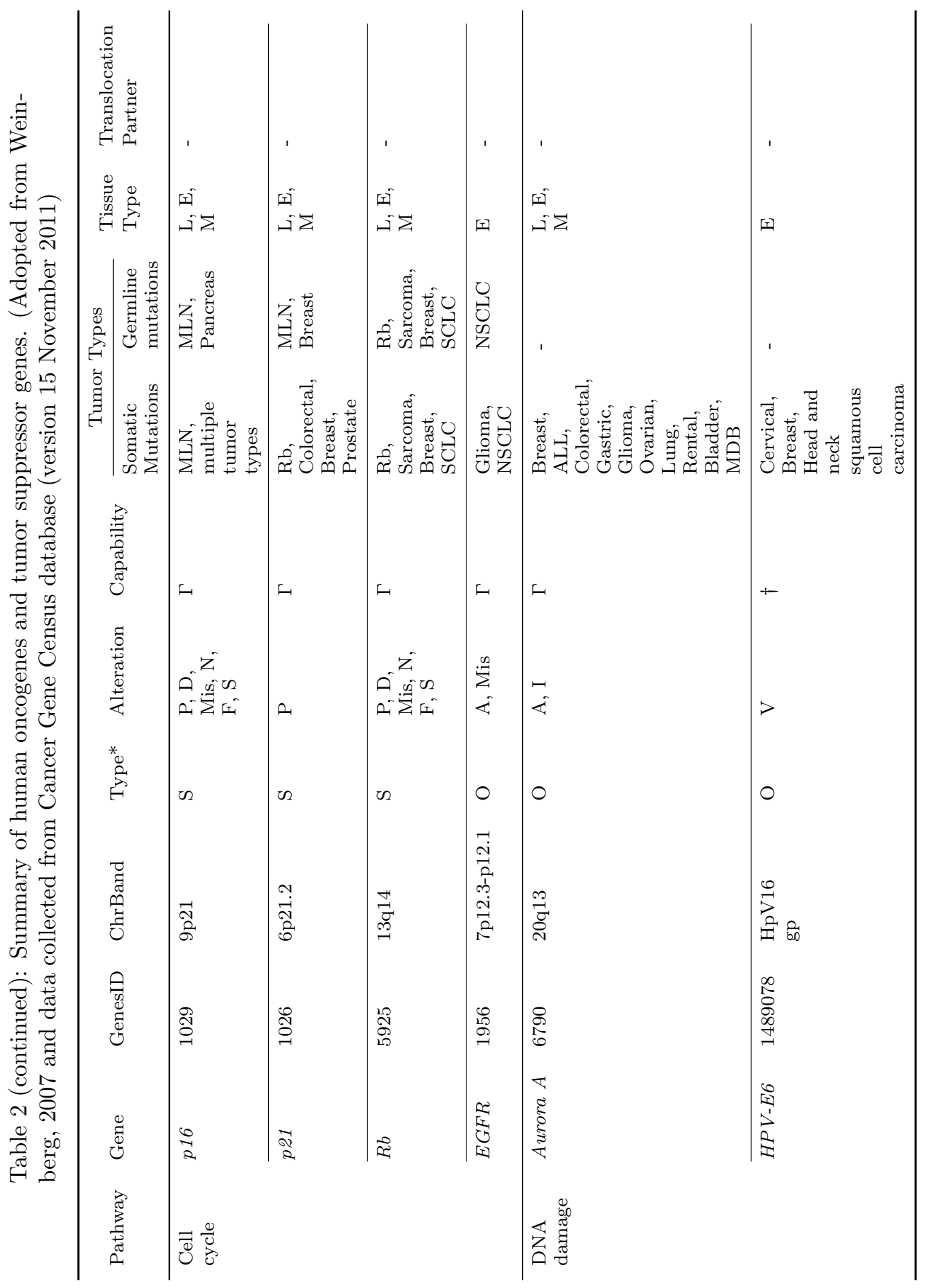




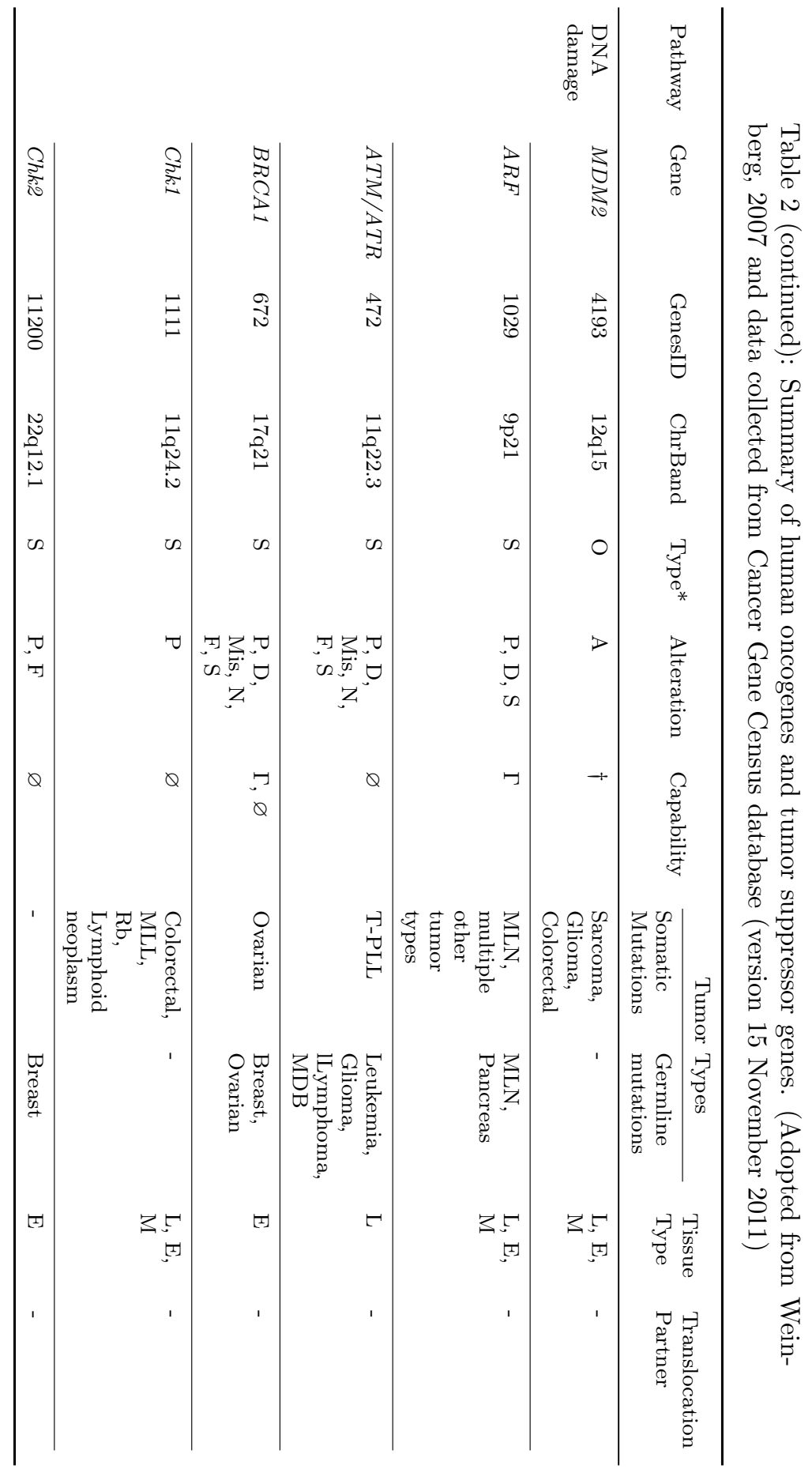




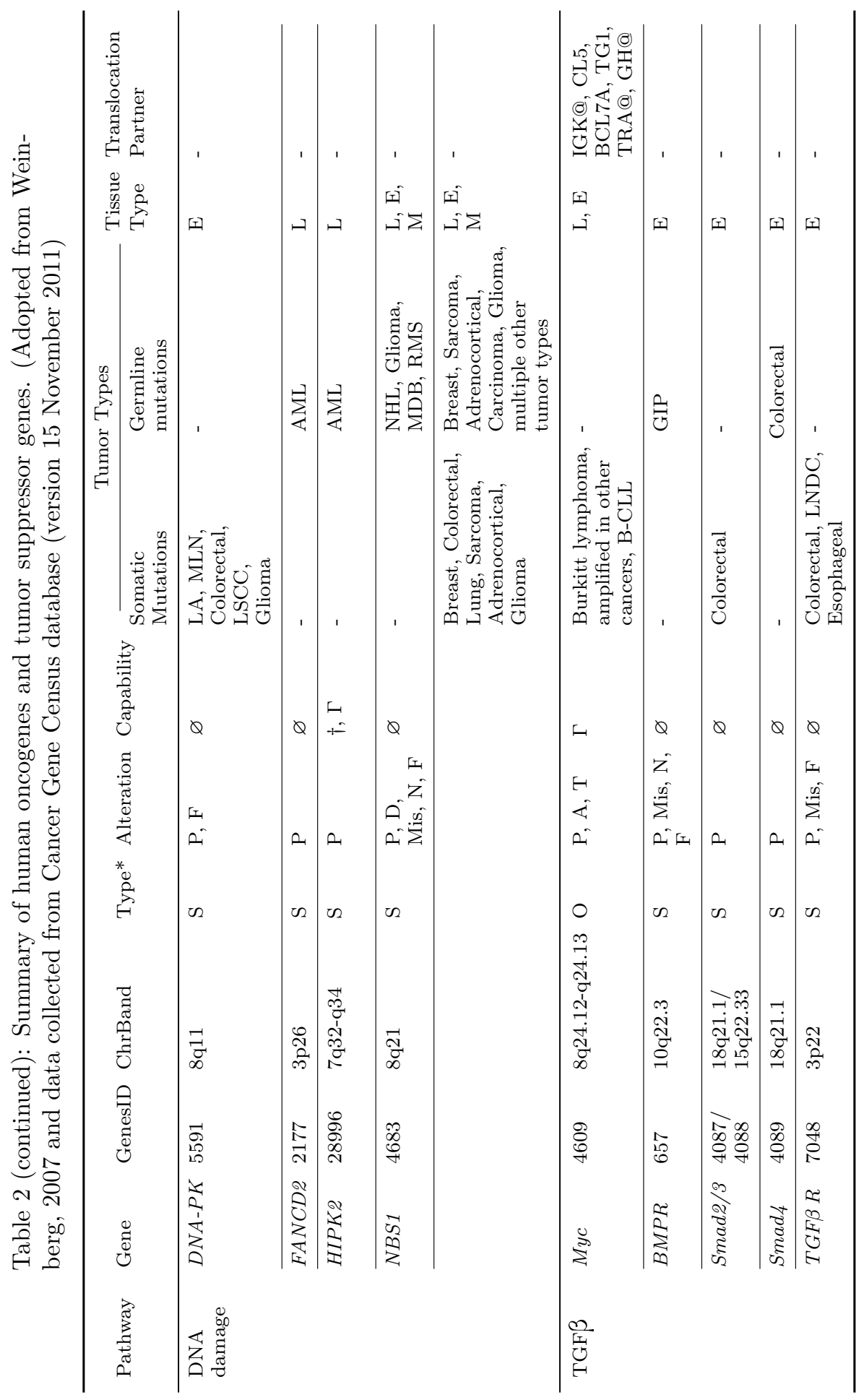




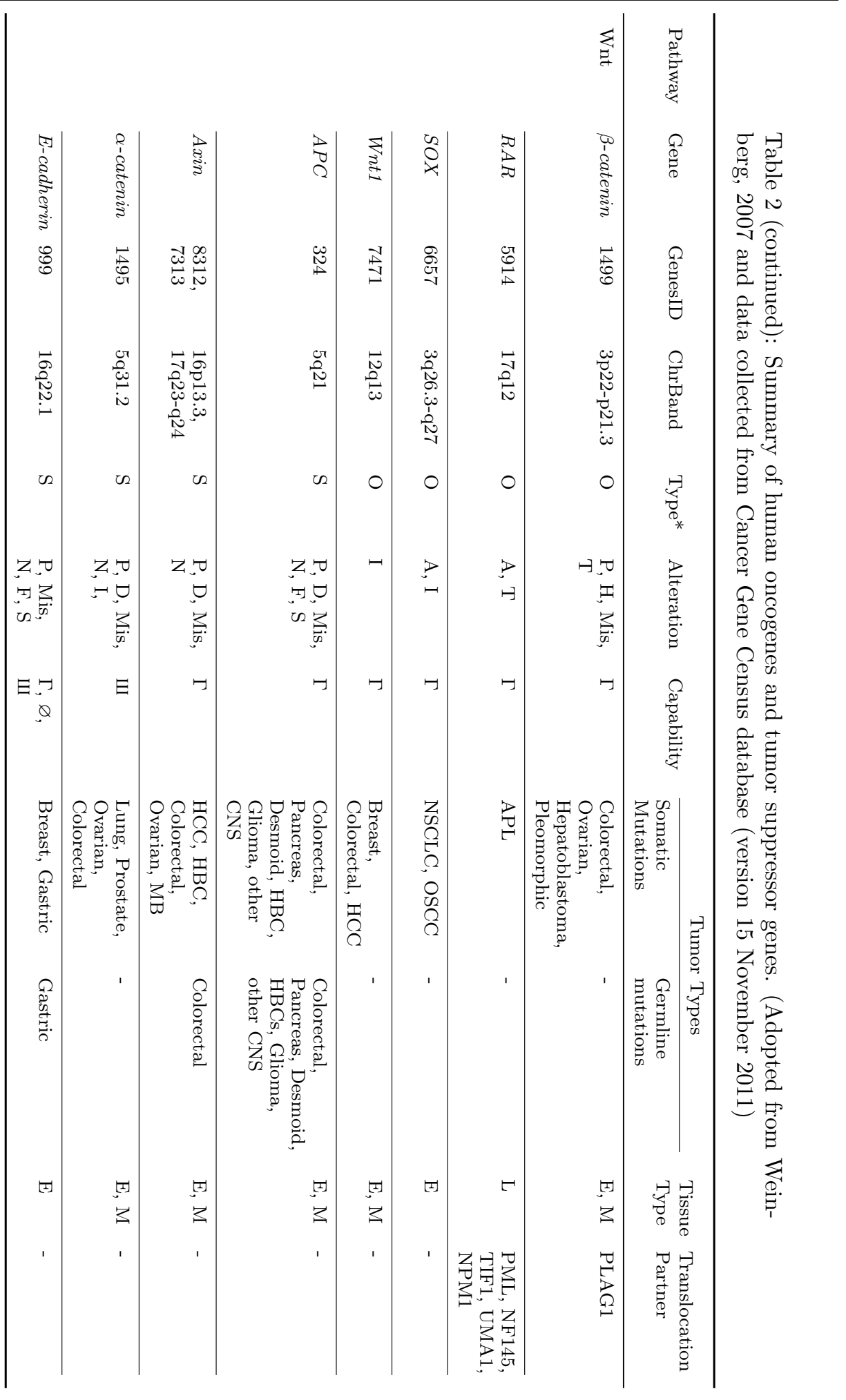




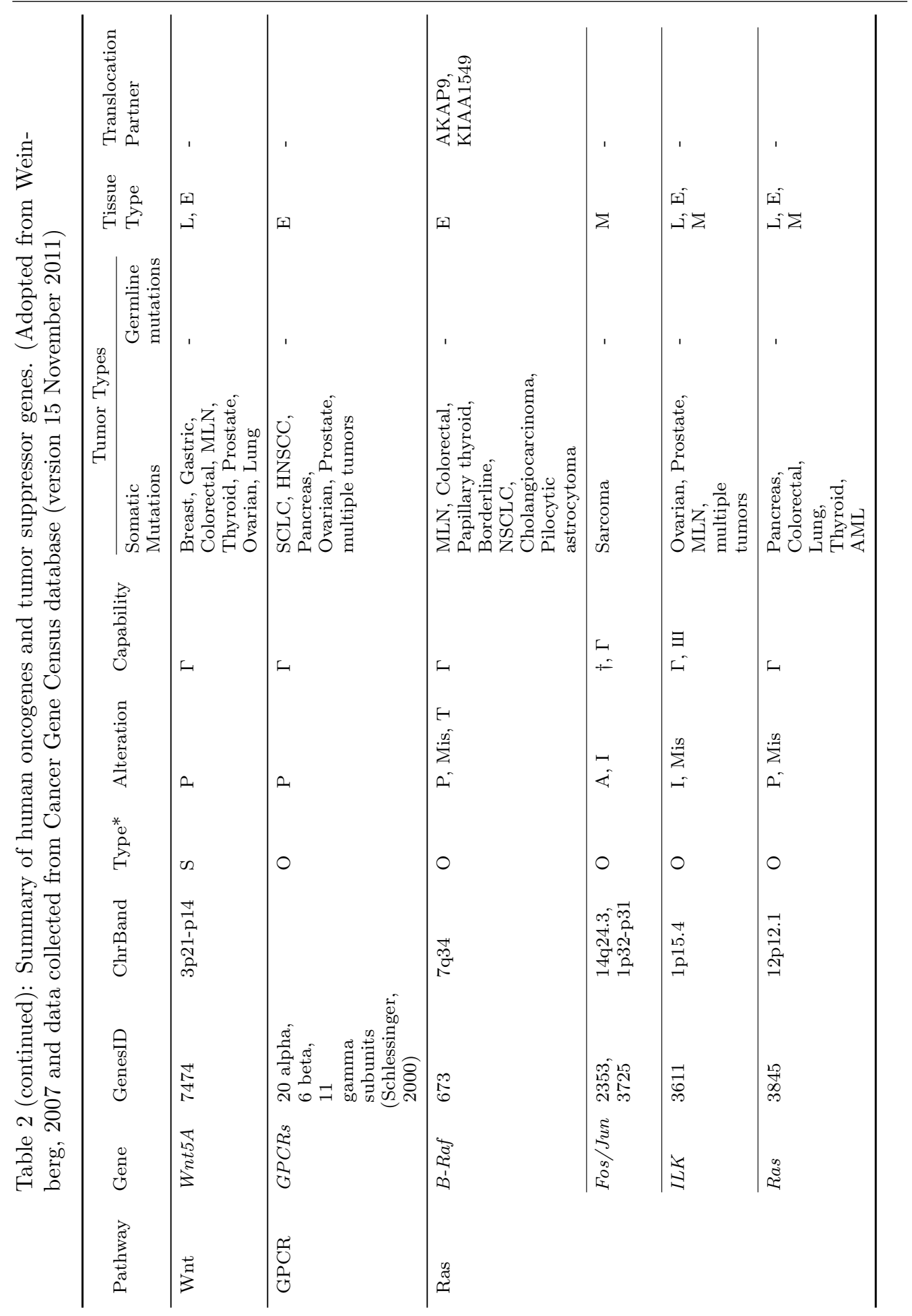



Nardnisa Sintupisut and Chen-Hsiang Yeang

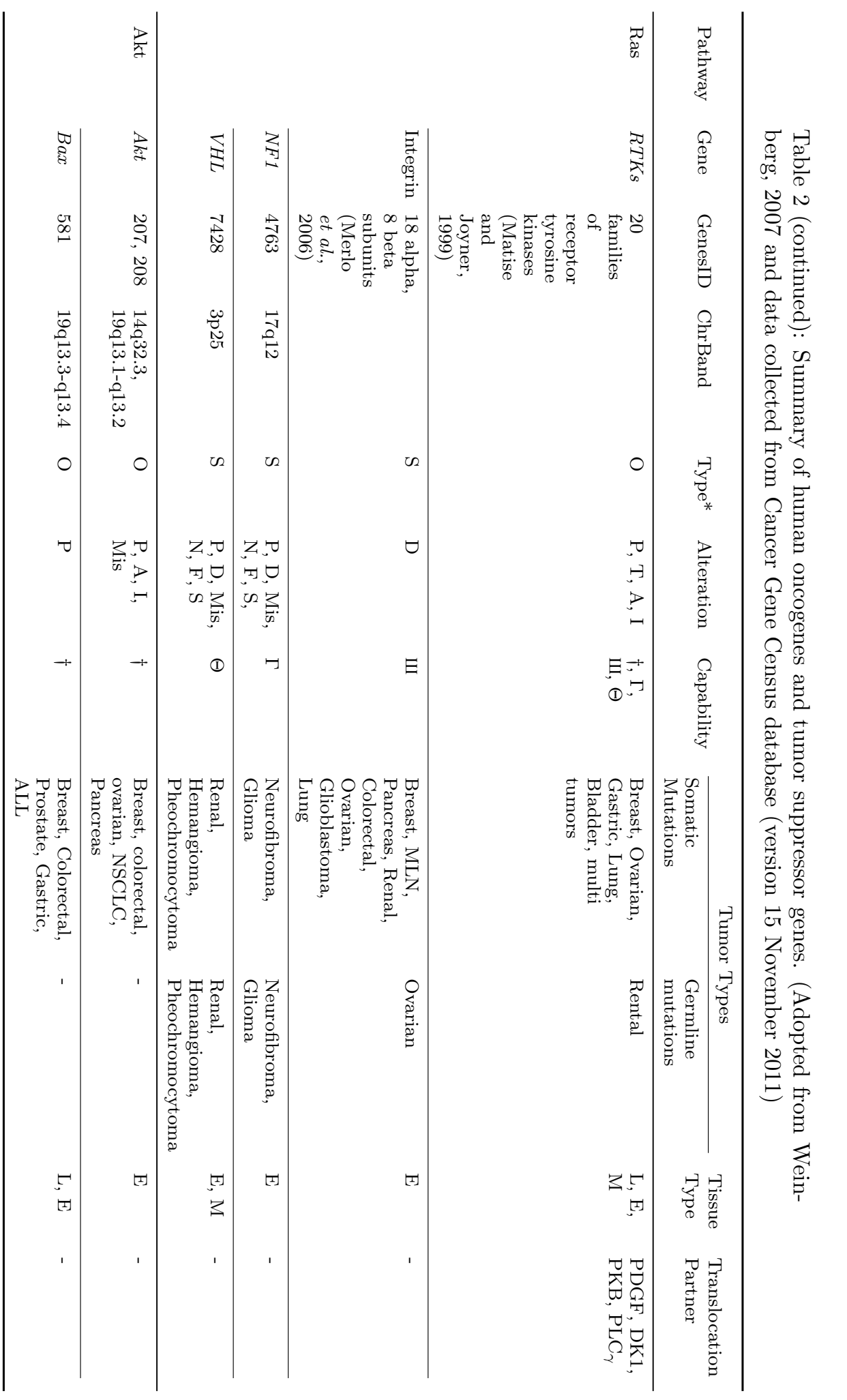




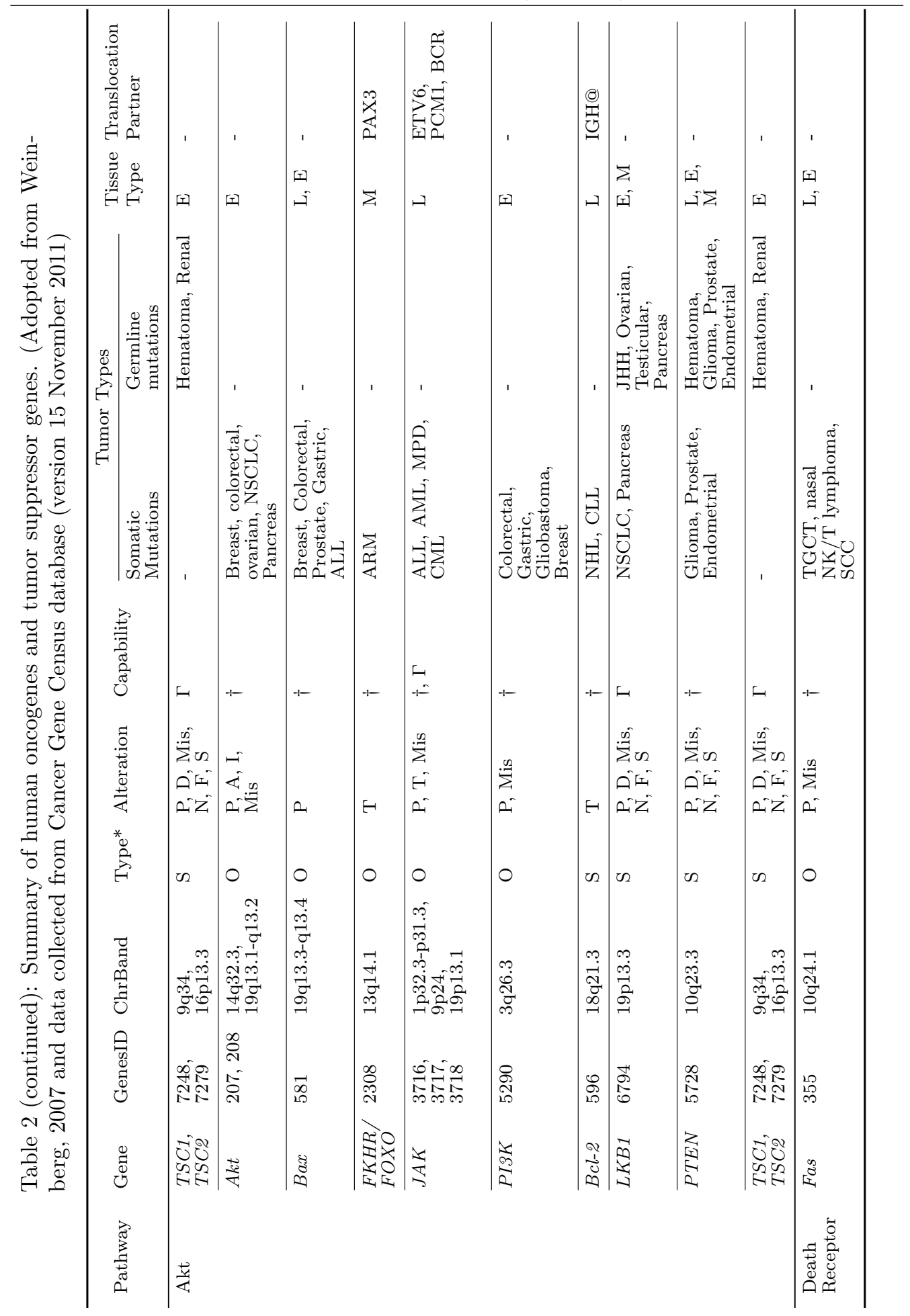


Sequence Mutations of Genes Pertaining to Malignancy in Cancer

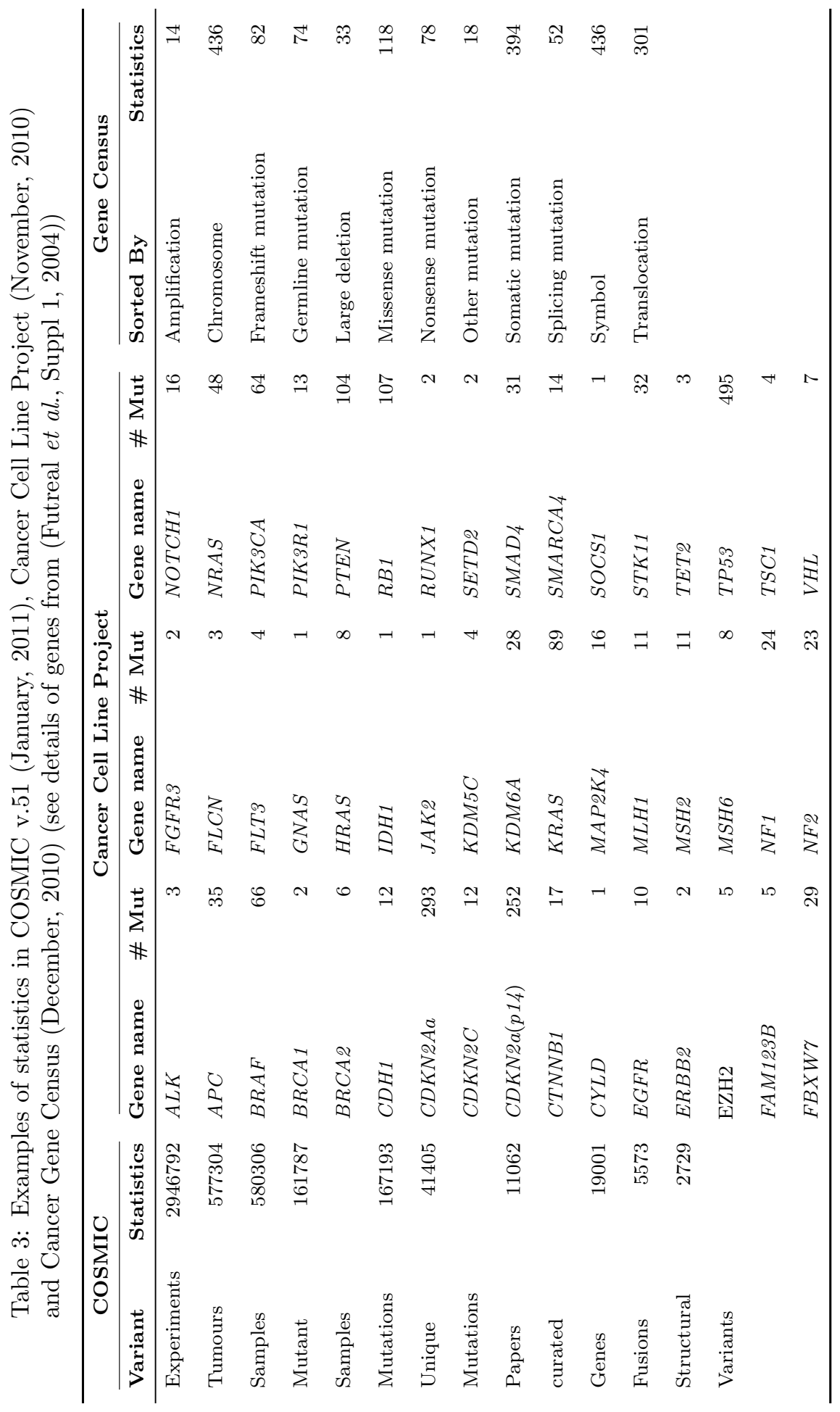




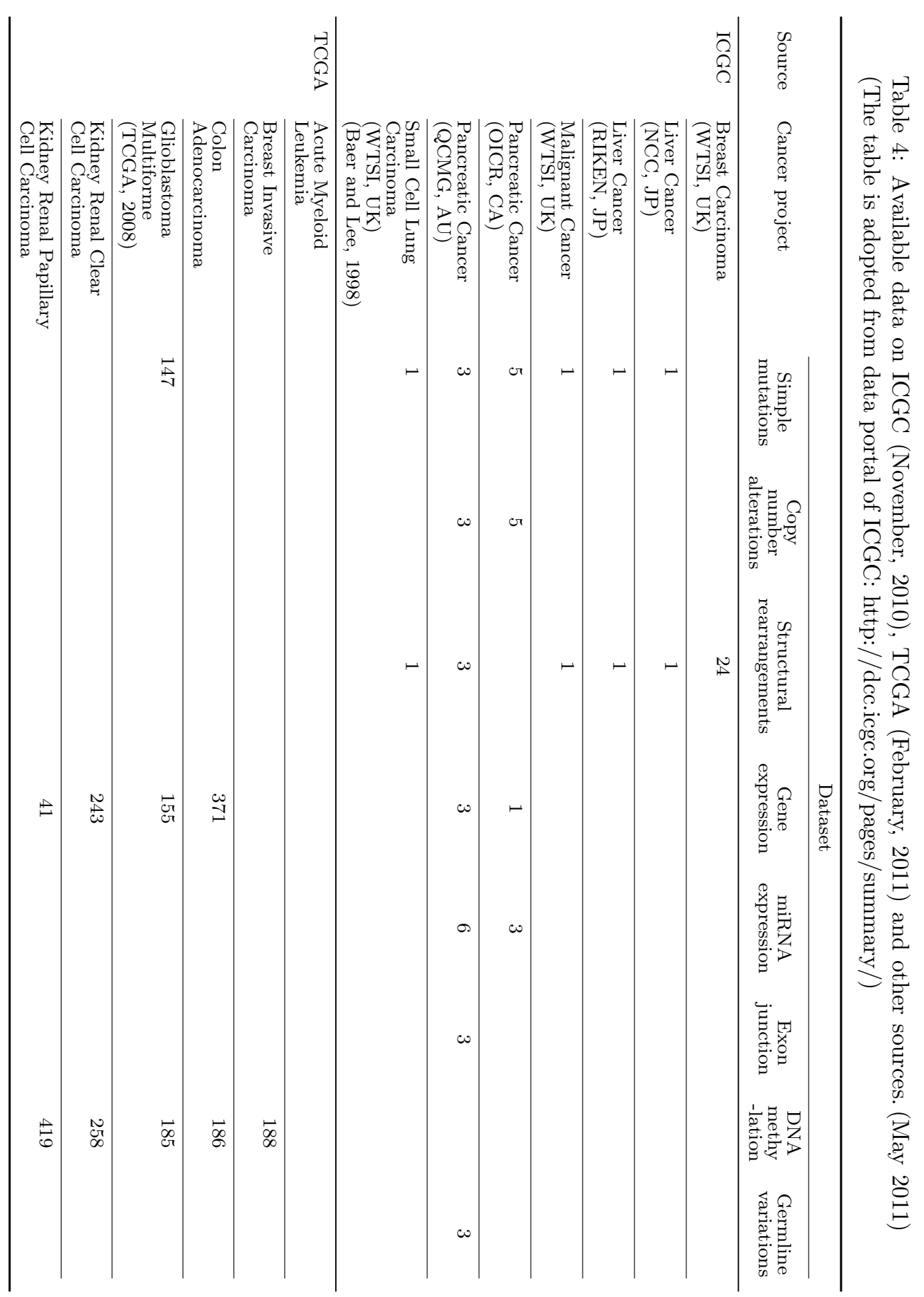




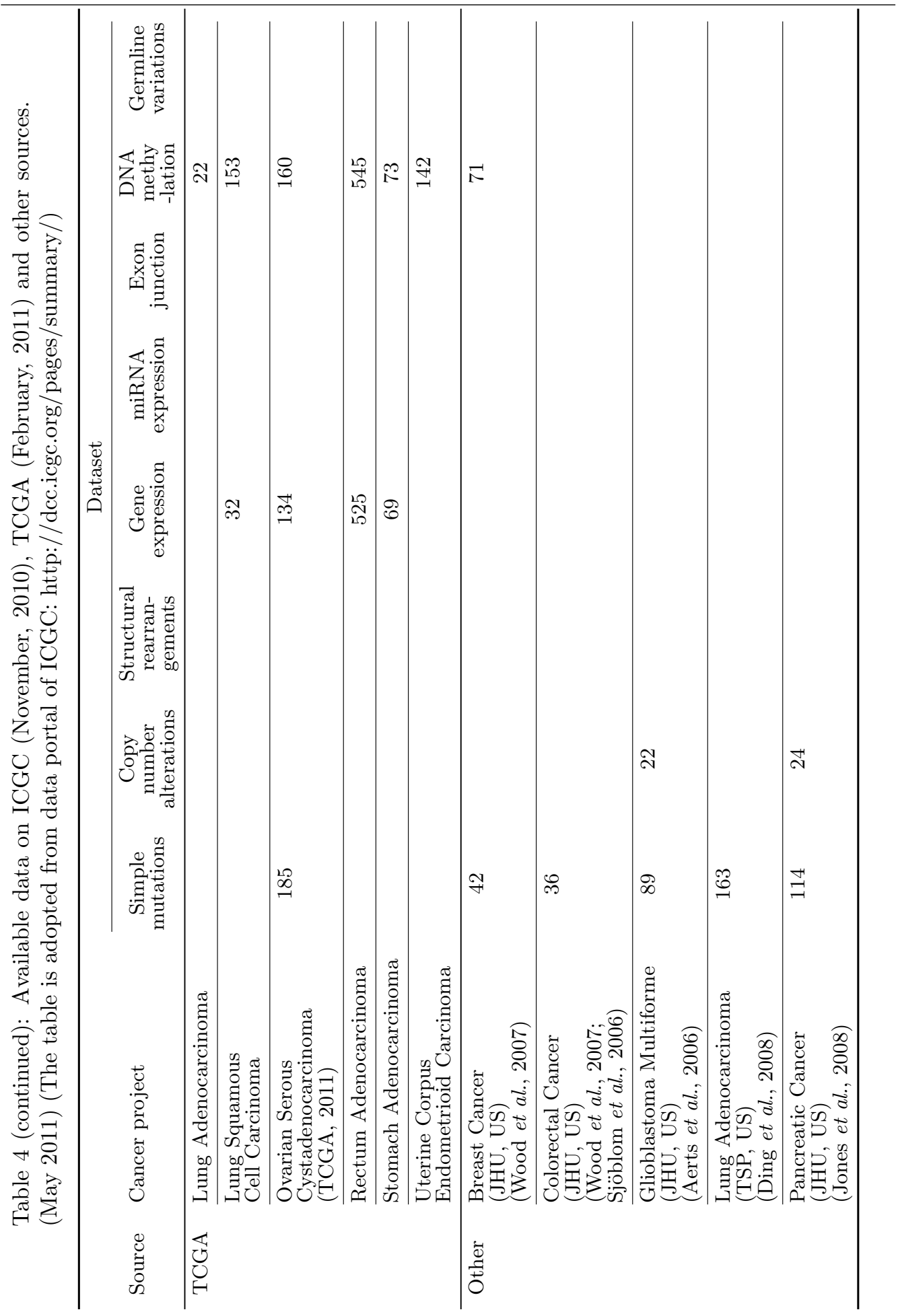


The Cancer Genome Atlas (TCGA) (http://tcga-data.nci.nih.gov/tcga/) is another international collaborative effort led by National Institute of Health (NIH) to comprehensively catalog somatic DNA changes from the genomes of cancer specimens and associated normal tissues in at least 400 to 1,000 cancer cases (TCGA, 2008). The International Cancer Genome Consortium (ICGC) (http://www.icgc.org/) is aiming for comprehensively characterizing somatic aberrations of at least fifty classes of cancers with high-coverage sequencing of 25,000 cancer genomes or more (ICGC, 2010). The released data of TCGA and ICGC are summarized in Table 4.

Broadly speaking, cancer genomic data can be divided into four levels: (I) raw, (II) processed or normalized, (III) interpreted, and (IV) summarized categories based on the degree of computational analysis applied to the data (Chin et al., 2011). Level I-III data correspond to individual samples, while level IV refers to analyses across datasets. Processed or normalized data represent the data that have been assigned to a genome reference such as alignment of sequences to reference genome or combination of multiple probes to a single value in a microarray. Interpreted data represent biological meanings extracted from each sample such as comparisons of expression profiles across the genes. Summarized data represent analysis of interpreted data across a cohort of samples. In order to protect patient privacy, access policies are applied to the data. Most raw data and some type of normalized data such as single nucleotide polymorphism profiles have controlled to limited users, while interpreted and summarized data are openly accessible to all users. Controlled-access data typically require a specific proposal of data use and approval by the institutional board of the requesting investigator. Sites of these databases including data structures and access policies are summarized in Chin et al. (2011), Table 2 and provided on the public website http://mib.stat.sinica.edu.tw/yeanggroup/public/cancerdb.

Up to date, challenges in analysis of cancer genome data are subjected to four aspects: (1) quality control (QC) of data, (2) accurate estimation of signal and noise in large data sets, (3) reproducible approaches to complex genomic analyses, and (4) achieving sufficient power in the face of multiple hypotheses testing (Chin et al., 2011). Biospecimen and technical execution are key factors contributing to raw data quality. Criteria in normalization step are important to remove any experimental artifacts that may negatively impact data quality. Platform-specific noise measures can be used to optimize data quality for each type of genomic measurement. Statistical and computational approaches are powerful tools to explore such large-scale genomic studies. There are various theoretical models predicting the functional consequence of specific nucleotide mutations. Beyond statistical analysis, these models are often constructed based on the functional impacts of specific amino acid mutations on protein structures or conserved domains either in two- or three-dimension. Statistical power is a principal concern for identify- 
ing biomarkers to distinguish between various phenotypes such as cancer versus normal samples. Since the feature size in these problems is typically far more than the sample size, adjustment of inference outcomes in multiple hypotheses testing such as Bonferroni correction (Abdi, 2007) or false discovery rates (FDR) (Benjamini and Hochberg, 1995) needs to be applied. However, the Bonferroni correction is too conservative for relevant variables (Perneger, 1998). Another challenge to validate the alteration patterns in cancer is the reproducibility of the findings in independent data sets. Computational tools such as meta-analysis across multiple datasets can facilitate validation of reproducible findings (Hong et al., 2006).

Cancer cells undergo alterations at multiple levels from DNA sequences and karyotypes to RNA expressions and protein modifications. Integrative analysis is a promising tool to reveal the multi-level information of cancer cells by combining the data from multiple types of assays. There are a number of efforts on data-integration in cancer genomics. For instance, predicting candidate tumor suppressor genes from genomic deletions, inactivating mutations, promoter hypermethylation, alterations of miRNA expression and/or transcriptional downregulation in different tumor samples (Dalgliesh et al., 2010), assessing pathway activities from sequence mutations and copy number variations of the member genes (TCGA, 2008), characterizing glioblastoma phenotypes with combinations of copy number variations and transcription profiles (Verhaak et al., 2010), and identifying key somatic driver mutations of small-cell lung cancer based integrative analyses (Peifer et al., 2012). In addition to the aforementioned studies, there are a number of books introducing broader principles and applications of computational methodologies in cancer studies. For instance, a textbook edited by Barillot et al. (2012) provides a comprehensive overview of the concepts and algorithms, principles of existing models/tools and relevant resources including real examples of biological applications, clinical aspects and biological questions in computational systems biology of cancer. A lecture note on mathematical modeling written by Wodarz and Komarova (2008) introduces the concept of mathematical modeling and a variety of applications in cancer biology such as somatic evolution of cells, genetic instability, and angiogenesis. The book also discusses the use of mathematical models for the analysis of therapeutic approaches such as chemotherapy, immunotherapy, and the use of oncolytic viruses. Juan (2011) published a textbook presenting an overview of the ongoing advances of genomics and proteomics in systems biology, coupled with the development of new and more robust tools in cancer-related research. As for statistical methods, the book series published by IARC $(1980,1986,1987,1994)$ cover principal issues in cancer research. The first volume (IARC, 1980) explains the statistical methods and theory behind the design, and the practical application to specific sets of data. It includes chapters on fundamental measures of disease occur- 
rence, general considerations for the analysis of case-control studies, analysis of grouped and ungrouped data, and use of unconditional and conditional logistic regressions. The second volume (IARC, 1986) provides a comprehensive account of the major types of studies in cancer epidemiology. Its scope ranges from an account of elementary and descriptive cohort analyses to the fitting of regression models for incidence rates with general risk functions. Particular attention is given to the use of a case-control approach embedded in a cohort study. As in the first volume, all methods are illustrated by examples from real studies, and the data are appended to the text, enabling readers to rework the computations. The third volume (IARC, 1987) addresses the design and analysis of measures to standardize methods for long-term animal experiments. This area of research is particularly important due to the biological limitations of short-term assays and the methodological difficulties of some epidemiological studies. The fourth volume (IARC, 1994) presents and discusses fundamental concepts, techniques for the analysis of cancer risk, space-time variations and group correlations and technique for survival analysis, that used in descriptive epidemiology which are relevant to cancer research.

\section{Common and Different Causes among Distinct Cancer Types}

Carcinogenesis is a multistep process requiring the accumulation of multiple genetic mutations. The common features of tumor cells include immortality, decreased dependence on growth factors to support proliferation, loss of anchoragedependent growth, loss of cell cycle control, reduced sensitivity to apoptotic cell death, and increased genetic instability. The mutations of genes that dysregulate the activities of these molecular features can consequently increase a risk of tumorigenesis. However, the development of cancer phenotypes among different tissues differs on selective constraints and trajectories of evolution (Merlo et al., 2006). Identification of the molecular aberrations characterizing the phenotypes of cancers is of great importance in their diagnosis and treatments. During 2004 to 2008, World Health Organization (WHO) has investigated cancer statistics in distinct cancer types via a project named GLOBOCAN (http://globocan.iarc.fr/). The aim of the project is to provide contemporary estimates of the incidence, mortality and prevalence from major type of cancers, at national level, for 184 countries of the world. The latest GLOBOCAN estimates are presented in 2008 (Ferlay et al., 2008). This review summarizes the common and distinct genetic mutations in five distinct cancer types possessing the highest incidence and mortality worldwide (lung, breast, colorectum, stomach and prostate), and another one cancer type (brain with glioblastoma multiforme) as the first effort of integrative analysis in cancer genomic data (TCGA, 2008). The cancer statistics and method summary in GLOBOCAN are shown in Table 5. The mutated genes and 
related pathways of several common cancer types are summarized in Table 2.

Table 5: Method and statistics summary of estimating age-standardized incidence, mortality and prevalence in male, female and both sexes (GLOBOCAN, 2008). Incidence: Population weighted average of the area-specific country rates applied to the 2008 area population. Mortality: Population weighted average of the area-specific country rates applied to the 2008 area population. Prevalence: Sum of area-specific prevalent cases. Age-standardised rate (W): A rate is the number of new cases or deaths per 100,000 persons per year. Risk of getting or dying from the disease before age $75(\%)$ : The probability or risk of individuals getting/dying from cancer

\begin{tabular}{lrrr}
\hline World & Male & Female & Both sexes \\
\hline Population (thousands) & 3414566 & 3358715 & 6773281 \\
Number of new cancer cases (thousands) & 6617.8 & 6044.7 & 12662.6 \\
Age-standardized rate (W) & 202.8 & 164.4 & 180.8 \\
Risk of getting cancer before age 75 (\%) & 21.1 & 16.5 & 18.6 \\
\hline Number of cancer deaths (thousands) & 4219.6 & 3345.2 & 7564.8 \\
Age-standardized rate (W) & 127.9 & 87.2 & 105.6 \\
Risk of dying from cancer before age 75 (\%) & 13.4 & 9.1 & 11.1 \\
\hline 5-year prevalent cases, & 13514.9 & 15288.3 & 28803.2 \\
adult population (thousands) & & & \\
Proportion (per 100,000) & 550.6 & 620.8 & 585.8 \\
\hline 5 most frequent cancers & Lung & Breast & Lung \\
(ranking defined by total number of cases) & Prostate & Colorectum & Breast \\
& Colorectum & Cervix uteri & Colorectum \\
& Stomach & Lung & Stomach \\
& Liver & Stomach & Prostate \\
\hline
\end{tabular}

Lung cancer is the leading cause of cancer mortality in both men and women in the United States (Travis et al., 1995) and has the highest incidence rate (age-standardized) of all cancers in the North America, Eastern Asia and Europe for males, and in the North America, Northern Europe, Eastern Asia, Australia and New Zealand for females (McDonald et al., 2008; Ferlay et al., 2008). Polymorphisms in interleukin-1 (Engels et al., 2007; Lind et al., 2005), cytochrome P450 (Wenzlaff et al., 2005), caspase-9 (Park et al., 2002), and nucleotide excision repair molecules (Park et al., 2006) render higher risks for lung cancer after exposure to carcinogens or mutagens. Genetic alterations in smokers and nonsmokers with lung cancers have different molecular profiles. Mutations and amplifications of the epidermal growth factor EGFR kinase domain commonly occur in the early development of adenocarcinoma, which is generally unrelated to smoking (Herbst and Schwartz, 2008). Mutations in the $K-R A S$ proto-oncogene occur more frequently among smoker patients and comprise 10-30\% of lung adenocarcinomas (Jančík et al., 2010). HER2 mutations and amplifications have been identified in patients with lung adenocarcnima (Stephens et al., 2004; Shigematsu et al., 
2005; Buttitta et al., 2006). Kinase domain mutations of HER2 and EGFR are associated with non-smoking Asian women with lung cancers (Shigematsu et al., 2005). Meanwhile, amplifications of HER2 are associated with sensitivity to inhibitors of EGFR tyrosine kinase (Herbst and Schwartz, 2008). Loss of heterozygosity can inactivate several tumor suppressors such as $p 53$ (Zienolddiny et al., 2001), c-MET (Ma et al., 2005), LKB1 (Sanchez-Cespedes et al., 2002), PIK3CA (Samuels and Velculescu, 2004), and BRAF (Brose et al., 2002). The mutations in these genes affect several major downstream signaling pathways including RasRaf-Mek and the pathway consisting of phosphoinositide 3-kinase (PI3K), Akt, and mammalian target of rapamycin (mTOR), which may participate in proliferation, invasion, metastasis, and tumor angiogenesis through pathways of hypoxia inducible factor (HIF) (Volm and Koomägi, 2000). These pathways may be modulated by other receptor tyrosine kinases, such as insulin-like growth factor 1 receptor (IGF-1R) and $c-M E T$, and by the LKB1-amp-activated protein kinase (AMPK) pathway (Herbst and Schwartz, 2008). Furthermore, other alterations such as methylation in promoter regions and microsatellite instability can occur in normal tissue surrounding non-small-cell lung tumors and may be associated with a risk of recurrence and second primary tumors (Park et al., 2000). In summary, these studies suggest that molecular origins and mechanisms of lung cancer are complex interactions between environment and genes.

Breast cancer is the most frequently diagnosed cancer and the leading cause of cancer deaths in women in both developed and developing countries (Jemal et al., 2011). A number of genes conferring risks of breast cancers have been identified, including BRCA1, BRCA2, ATM, TP53, CHEK2, PTEN, CDH1 and SKT11. Mutations on these genes can be either inherited or acquired (Ergül and Sazc, 2001). The inherited mutations of BRCA1 and BRCA2 are the most common cause of hereditary breast cancer. Women carrying $B R C A 1$ or BRCA2 mutations possess a risk $80 \%$ higher than women without inherited mutations. ATM is involved in DNA damage repeat. Mutations on one or two copies of this gene yield a high rate of breast cancer and the disease ataxia-telangiectasia. Inherited mutations of $p 53$ and CHECK2 cause the Li-Fraumeni syndrome and elevate the risk of breast cancer (Vickie and Saundra, 2010). Inherited mutations in PTEN lead to Cowden syndrome, a rare disorder that increases risk for both benign and malignant breast cancer (Lynch et al., 1997). Inherited mutations in CDH1 indirectly increase risk of invasive lobular breast cancer via a hereditary diffuse gastric cancer (Graziano et al., 2003). The defects in STK11 can lead to PeutzJeghers syndrome, a disorder in which people have pigmented spots on their lips, mouths, polyps in urinary and gastrointestinal tracts, and suffer an increasing risk of breast cancer (Hearle et al., 2006). Most of these mutations are related to several signaling cascades involved in growth factor receptors and apoptosis (Lynch et al., 1997). High PI3K/PTEN/Akt activities inhibit apoptosis and 
activate all cycle progression, whereas high Raf activities induce growth arrest and differentiation (Steelman et al., 2011). Amplification of HER2, a receptor tyrosine kinase $(R T K)$, occurs in approximately $30 \%$ of breast cancer and lead to increased expression of both the Ras/PI3K/Akt/PTEN/mTOR and Ras/Raf/MEK/ERK pathways. In addition, many studies have examined that women with higher levels of estrogen tend to develop breast cancer (Thomas et al., 1997). Estrogen can indirectly stimulate cell division by activating a variety of hormone receptors. The mechanisms of how estrogens contribute to each phase of the carcinogenesis are still unclear. Two pathways are suspected to play important role in cell proliferation and apoptosis in mammary tissues: genotoxic estrogen metabolism and estrogen-receptor-mediated genomic and nongenomic signaling (Thomas et al., 1997; Clemons and Goss, 2001; Yager et al., 2006). However, the factors driving these pathways require further investigation (Yager et al., 2006).

Colorectal cancer is the third most commonly diagnosed cancer worldwide and more common in developed countries (Jemal et al., 2011). Mutations in the WntAPC-beta-catenin signaling increase the signaling activity in the intestinal crypt stem cells (Segditsas and Tomlinson, 2006). The most commonly mutated gene in all colorectal cancer is $A P C$. The $A P C$ protein interrupts stem cell renewal and differentiation by inducing high level of $\beta$-catenin protein accumulation. Mutations of TP53 can transform an adenoma into an invasive carcinoma (Iacopetta, 2003). Other apoptotic proteins commonly deactivated in colorectal cancers are TGF- $\beta$ and DCC (Markowitz, 2009). In addition, some common oncogenes such as KRAS, RAF and PI3K are overexpressed in colorectal cancers (De Roock et al., 2010).

Stomach cancer, also-called gastric cancer, is one of the leading causes of cancer mortality worldwide with more than 700,000 deaths each year (Ferlay et al., 2008). Stomach cancer is more common in men and most people diagnosed are over 70 years old. Stomach cancer usually begins in cells in the inner layer of the stomach. Over time, the cancer may invade more deeply into the stomach wall, and spread to surrounding organs such as liver, pancreas, esophagus, or intestine. In term of genetic alterations, gastric carcinoma organizes different patterns of interplay between neoplastic and stromal cells through the growth factor/cytokine receptor system, which has a critical role in cell growth, apoptosis, morphogenesis, angiogenesis and metastasis. Other genetic factors, such as genetic instability and DNA polymorphism are associated with increased risk levels. Two interdependent phenotypes of genomic instability are generally recognized in gastric cancer: microsatellite instability (MSI) and chromosomal instability (CIN). MSI is a common feature of gastric cancer pertaining to the DNA mismatch repair system and the DNA replication errors in simple repetitive sequences (Imai and Yamamoto, 2008). Functional inactivation by mutations or epigenetic mecha- 
nisms of mismatch repair genes such as $h M L H 1$ and $h M S H 2$ has been discovered (Simpson et al., 2001). MSI-related mutations occur in genes regulating cellcycle and apoptotic signaling including TGF RRII, IGFIIR, TCF4, RIZ, BAX, CASPASE5, FAS, BCL10 and APAF1 (Lacopetta et al., 1999). In addition, genes involved in genomic integrity maintenance such as $h M S H 6, h M S H 3, M E D 1$, RAD50, BLM, ATR and MRE11, are also frequently altered (Ottini, 2004). CIN is a common feature associated with chromosomal aberrations corresponding to major modifications of DNA content. For example, changes in chromosome copy number, high level LOH, gene deletions and/or amplifications (Sugai et al., 2005; Sánchez-Pérez et al., 2009). All these alterations may lead to oncogene activation and/or tumor suppressor gene inactivation. The methylation of $\mathrm{CpG}$ islands and tumor related genes such as APC, CDH1, DKK3, PTEN, MGMT, MHL1, $C D K N 2 A, C D K N 2 B$ and $R U N X 3$ have been widely reported in gastric cancer. Genetic and genomic variations occurring in genes and molecules that participate in proliferation, invasion and metastasis (e.g., growth factors and their receptors, signal transducers, cell-cycle and apoptosis regulators, cell adhesion molecules, DNA repair genes and matrix metalloproteinases) may influence the prognosis of patients with gastric cancer. The genes under these pathways such as $p 53, p 21$, p27, BCL2, BAX, pRb, c-myc, Clyclin E, E-cadherin, MUC1 and PRL-3 have been investigated (Nobili et al., 2011).

Prostate cancer is the third most common cause of cancer mortality in males of all ages, worldwide (Guo and Wang, 2009). The highest incidence rates are in the developed countries of Oceania, Europe, and North America, whereas the mortality rates rise more rapidly in Asian countries (Hsing et al., 2000; Jemal et al., 2011). RUNX2 is a transcription factor that prevents cancer cells from undergoing apoptosis (Leav et al., 2010). The PI3k/Akt signaling cascade cooperates with the transforming growth factor beta/SMAD signaling cascade to facilitate prostate cancer cell survival and protection against apoptosis (Guo and Wang, 2009). X-linked inhibitor of apoptosis (XIAP) is an inhibitor of apoptosis cascade (Straszewski-Chavez et al., 2004). Macrophage inhibitory cytokine-1 (MIC-1) stimulates the focal adhesion kinase (FAK) signaling pathway, which facilitates prostate cancer proliferation (Senapati et al., 2010). In addition, the androgen receptor is intensively examined for its function on cell proliferation (Zou et al., 2009).

Brain tumors in recent years have replaced leukemia as the leading cause of cancer-related mortality in children (Lag et al., 2011). Glioblastoma Multiforme $(\mathrm{GBM})$ is the most common malignant brain tumor in adults (Travis et al., 1995; TCGA, 2008; Verhaak et al., 2010). Glioblastoma pathogenesis is associated with deregulation of three pathways: the RTK/RAS/PI3K pathway, the $\mathrm{CDK} /$ cyclin/CDK inhibitor/RB pathway, and the $p 53$ pathway (Verhaak et al., 
2010; Klinz et al., 2011). In the RTK/PI3K pathway, PTEN is frequently deleted and mutated. Amplifications or point mutations in EGFR, ERBB2, PDGFRA and $M E T$ are suggested to co-activate the RTKs mechanism. Inactivation of the p53 pathway can occur when homozygous deletions of the CDKN2A locus encoding both $\mathrm{p} 16^{\mathrm{INK} 4 \mathrm{~A}}$ and $A R F$, and amplifications of MDM2 and MDM4 occur. Inactivation of $R B 1$ by nucleotide substitutions can prevent the genetic pressure for activation of upstream cyclin/cyclin-dependent kinases. Subtypes of GBM tend to posses different mutational signatures. In classical subtypes, EGFR amplifications and PTEN mutations occur more frequently, where as TP53 and PDGFRA/IDH1, and NF1 mutations occur more commonly in proneural and mesenchymal subtypes (Klinz et al., 2011). However, none of these alterations can distinguish subtypes of GBMs with high accuracy.

\section{Conclusion}

With high-throughput technologies such as SNP arrays and next-generation sequencing, the genome-wide landscape of sequence mutations is being mapped. This mutational landscape suggests that sequence mutations result from an evolutionlike process. While a few cancer-related genes exhibit frequent, tissue-specific mutations and specific combinatorial mutational patterns, a large number of passenger mutations are sporadic and do not carry obvious functional consequences. However, the mutations of these well-known genes are certainly not sufficient conditions for tumorigenesis. Other types of molecular aberrations (such as epigenetic changes), biological processes beyond standard cell cycle control and apoptosis pathways (such as compromise of immune systems), small but significant effects from common variations, and interactions with environmental factors all play important roles in tumor generation. It remains a grand challenge to collect these types of information and use them to decipher the molecular mechanisms of cancer. Moreover, integrative analysis of the collected multi-modal data is a critical step toward a comprehensive understanding of oncogenesis.

\section{Acknowledgements}

This study is financially supported by the Institute of Statistical Science, Academia Sinica, Taiwan.

\section{References}

Abdi, H. (2007). Bonferroni and Šidák corrections for multiple comparisons. In Encyclopedia of Measurement and Statistics (Edited by N. J. Salkind), 103-107. Sage, Thousand Oaks, California. 
Aerts, S., Lambrechts, D., Maity, S., Loo, P. V., Coessens, B., De Smet, F., Tranchevent, L. C., De Moor, B., Marynen, P., Hassan, B., Carmeliet, P. and Moreau, Y. (2006). Gene prioritization through genomic data fusion. Nature Biotechnology 24, 537-544.

Antoniou, A. C. and Easton, D. F. (2006). Models of genetic susceptibility to breast cancer. Oncogene 25, 5898-5905.

Artandi, S. E. and DePinho, R. A. (2010). Telomeres and telomerase in cancer. Carcinogenesis 31, 9-18.

Bardelli, A., Parsons, D. W., Silliman, N., Ptak, J., Szabo, S., Saha, S., Markowitz, S., Willson, J. K. V., Parmigiani, G., Kinzler, K. W., Vogelstein, B. and Velculescu, V. E. (2003). Mutational analysis of the tyrosine kinome in colorectal cancers. Science 300, 949.

Barillot, E., Calzone, L., Hupé, P., Vert, J. P. and Zinovyev, A. (2012). Computational Systems Biology of Cancer. In Chapman \& Hall/CRC Mathematical and Computational Biology (Edited by N. F., Britton, X. Lin, H. M. Safer, M. Singh and A. Tramontano). CRC Press, New York.

Baudot, A., Real, F. X., Izarzugaza, J. M. G. and Valencia, A. (2009). From cancer genomes to cancer models: bridging the gaps. EMBO Reports 10, 359-366.

Benjamini, Y. and Hochberg, Y. (1995). Controlling the false discovery rate: a practical and powerful approach to multiple testing. Journal of the Royal Statistical Society, Series B 57, 289-300.

Bignell, G. R., Greenman, C. D., Davies, H., Butler, A. P., Edkins, S., Andrews, J. M., Buck, G., Chen, L., Beare, D., Latimer, C., Widaa, S., Hinton, J., Fahey, C., Fu, B., Swamy, S., Dalgliesh, G. L., Teh, B. T., Deloukas, P., Yang, F., Campbell, P. J., Futreal, P. A. and Stratton, M. R. (2010). Signatures of mutation and selection in the cancer genome. Nature 463, 893-898.

Bodmer, W. and Loeb, L. A. (2008). Genetic instability is not a requirement for tumor development. Cancer Research 68, 3558-3561.

Brose, M. S., Volpe, P., Feldman, M., Kumar, M., Rishi, I., Gerrero, R., Einhorn, E., Herlyn, M., Minna, J., Nicholson, A., Roth, J. A., Albelda, S. M., Davies, H., Cox, C., Brignell, G., Stephens, P., Futreal, P. A., Wooster, R., Stratton, M. R. and Weber, B. L. (2002). BRAF and RAS mutations in human lung cancer and melanoma. Cancer Research 62, 6997-7000. 
Brown, J. R., Levine, R. L., Thompson, C., Basile, G., Gilliland, D. G. and Freedman, A. S. (2008). Systematic genomic screen for tyrosine kinase mutations in CLL. Leukemia 22, 1966-1969.

Buttitta, F., Barassi, F., Fresu, G., Felicioni, L., Chella, A., Paolizzi, D., Lattanzio, G., Salvatore, S., Camplese, P. P., Rosini, S., Iarussi, T., Mucilli, F., Sacco, R., Mezzetti, A. and Marchetti, A. (2006). Mutational analysis of the HER2 gene in lung tumors from Caucasian patients: mutations are mainly present in adenocarcinomas with bronchioloalveolar features. International Journal of Cancer 119, 2586-2591.

Chin, L., Hahn, W. C., Getz, G. and Meyerson, M. (2011). Making sense of cancer genomic data. Genes \& Development 25, 534-555.

Clemons, M. and Goss, P. (2001). Estrogen and the risk of breast cancer. New England Journal of Medicine 344, 276-285.

Clifford, R. J., Edmonson, M. N., Nguyen, C. and Buetow, K. H. (2004). Largescale analysis of non-synonymous coding region single nucleotide polymorphisms. Bioinformatics 20, 1006-1014.

Dalgliesh, G. L., Furge, K., Greenman, C., Chen, L., Bignell, G., Butler, A., Davies, H., Edkins, S., Hardy, C., Latimer, C., Teague, J., Andrews, J., Barthorpe, S., Beare, D., Buck, G., Campbell, P. J., Forbes, S., Jia, M., Jones, D., Knott, H., Kok, C. Y., Lau, K. W., Leroy, C., Lin, M. L., McBride, D.J., Maddison, M., Maguire, S., McLay, K., Menzies, A., Mironenko, T., Mulderrig, L., Mudie, L., O'Meara, S., Pleasance, E., Rajasingham, A., Shepherd, R., Smith, R., Stebbings, L., Stephens, P., Tang, G., Tarpey, P. S., Turrell, K., Dykema, K. J., Khoo, S. K., Petillo, D., Wondergem, B., Anema, J., Kahnoski, R. J., Teh, B. T., Stratton, M. R. and Futreal, P. A. (2010). Systematic sequencing of renal carcinoma reveals inactivation of histone modifying genes. Nature 463, 360-363.

Davies, H., Hunter, C., Smith, R., Stephens, P., Greenman, C., Bignell, G., Teague, J., Butler, A., Edkins, S., Stevens, C., Parker, A., O’Meara, S., Avis, T., Barthorpe, S., Brackenbury, L., Buck, G., Clements, J., Cole, J., Dicks, E., Edwards, K., Forbes, S., Gorton, M., Gray, K., Halliday, K., Harrison, R., Hills, K., Hinton, J., Jones, D., Kosmidou, V., Laman, R., Lugg, R., Menzies, A., Perry, J., Petty, R., Raine, K., Shepherd, R., Small, A., Solomon, H., Stephens, Y., Tofts, C., Varian, J., Webb, A., West, S., Widaa, S., Yates, A., Brasseur, F., Cooper, C.S., Flanagan, A. M., Green, A., Knowles, M., Leung, S. Y., Looijenga, L.H., Malkowicz, B., Pierotti, M. A., Teh, B. T., Yuen, S. T., Lakhani, S. R., Easton, D. F., Weber, B. L., 
Goldstraw, P., Nicholson, A. G., Wooster, R., Stratton, M. R. and Futreal, P. A. (2005). Somatic mutations of the protein kinase gene family in human lung cancer. Cancer Response 65, 7591-7595.

De Roock, W., Claes, B., Bernasconi, D., De Schutter, J., Biesmans, B., Fountzilas, G., Kalogeras, K. T., Kotoula, V., Papamichael, D., Laurent-Puig, P., Penault-Llorca, F., Rougier, P., Vincenzi, B., Santini, D., Tonin,i G., Cappuzzo, F., Frattini, M., Molinari, F., Saletti, P., De Dosso, S., Martini, M., Bardelli, A., Siena, S., Sartore-Bianchi, A., Tabernero, J., Macarulla, T., Di Fiore, F., Gangloff A, O., Ciardiello, F., Pfeiffer, P., Qvortrup, C., Hansen, T. P., Van Cutsem, E., Piessevaux, H., Lambrechts, D., Delorenzi, M. and Tejpar, S. (2010). Effects of KRAS, BRAF, NRAS, and PIK3CA mutations of the efficacy of cetuximab plus chemotherapy in chemotherapy-refractory metastatic colorectal cancer: a retrospective consortium analysis. Lancet Oncology 11, 753-762.

Ding, L., Getz, G., Wheeler, D. A., Mardis, E. R., McLellan, M. D., Cibulskis, K., Sougnez, C., Greulich, H., Muzny, D. M., Morgan, M. B., Fulton, L., Fulton, R. S., Zhang, Q., Wendl, M. C., Lawrence, M. S., Larson, D. E., Chen, K., Dooling, D. J., Sabo, A., Hawes, A. C., Shen, H., Jhangiani, S. N., Lewis, L. R., Hall, O., Zhu, Y., Mathew, T., Ren, Y., Yao, J., Scherer, S. E., Clerc, K., Metcalf, G. A., Ng, B., Milosavljevic, A., Gonzalez-Garay, M. L., Osborne, J. R., Meyer, R., Shi, X., Tang, Y., Koboldt, D. C., Lin, L., Abbott, R., Miner, T. L., Pohl, C., Fewell, G., Haipek, C., Schmidt, H., Dunford-Shore, B. H., Kraja, A., Crosby, S. D., Sawyer, C. S., Vickery, T., Sander, S., Robinson, J., Winckler, W., Baldwin, J., Chirieac, L. R., Dutt, A., Fennell, T., Hanna, M., Johnson, B. E., Onofrio, R. C., Thomas, R. K., Tonon, G., Weir, B. A., Zhao, X., Ziaugra, L., Zody, M. C., Giordano, T., Orringer, M. B., Roth, J. A., Spitz, M. R., Wistuba, I. I., Ozenberger, B., Good, P. J., Chang, A. C., Beer, D. G., Watson, M. A., Ladanyi, M., Broderick, S., Yoshizawa, A., Travis, W. D., Pao, W., Province, M. A., Weinstock, G. M., Varmus, H. E., Gabriel, S. B., Lander, E. S., Gibbs, R. A., Meyerson, M. and Wilson, R. K. (2008). Somatic mutations affect key pathways in lung adenocarcinoma. Nature 455, 1069-1075.

Drexler, H. G., Borkhardt, A. and Janssen, J. W. (1995). Detection of chromosomal translocations in leukemia-lymphoma cells by polymerase chain reaction. Leukemia Lymphoma 19, 359-380.

Edmunds, S. C. (2008). Chapter 7: genetics and cancer. In Biology of Cancer (Edited by J. Gabriel), 2nd edition, 63-78. Hoboken, Wiley, New Jersey. 
Ekins, S., Nikolsky, Y., Bugrim, A., Kirillov, E. and Nikolskaya, T. (2007). Pathway mapping tools for analysis of high content data. Methods in Molecular Biology 356, 319-350.

Engels, E. A., Wu, X., Gu, J., Dong, Q., Liu, J. and Spitz, M. R. (2007). Systematic evaluation of genetic variants in the inflammation pathway and risk of lung cancer. Cancer Research 67, 6520-6527.

Ergül, E. and Sazci, A. (2001). Molecular genetics of breast cancer. Turkish Journal of Medical Sciences 31, 1-14.

Ferlay, J., Shin, H. R., Bray, F., Forman, D., Mathers, C. and Parkin, D. M. (2008). GLOBOCAN 2008 v2.0, cancer incidence and mortality worldwide: IARC CancerBase No. 10. http://globocan.iarc.fr/.

Ferrer-Costa, C., Gelpi, J. L., Zamakola, L., Parraga, I., de la Cruz, X. and Orozco, M. (2005). PMUT: a web-based tool for the annotation of pathological mutations on proteins. Bioinformatics 21, 3176-3178.

Forbes, S. A., Tang, G., Bindal, N., Bamford, S., Dawson, E., Cole, C., Kok, C. Y., Jia, M., Ewing, R., Menzies, A., Teague, J. W., Stratton, M. R. and Futreal, P. A. (2010). COSMIC (the Catalogue of Somatic Mutations in Cancer): a resource to investigate acquired mutations in human cancer. Nucleic Acids Research 38, D652-D657.

Forbes, S.A., Bindal, N., Bamford, S., Cole, C., Kok, C. Y., Beare, D., Jia, M., Shepherd, R., Leung, K., Menzies, A., Teague, J. W., Campbell, P. J., Stratton, M. R. and Futreal, P. A. (2011). COSMIC: mining complete cancer genomes in the Catalogue of Somatic Mutations in Cancer. Nucleic Acids Research 39, D945-D950.

Furney, S. J., Calvo, B., Larrañaga, P., Lozano, J. A. and Lopez-Bigas, N. (2008). Prioritization of candidate cancer genes-an aid to oncogenomic studies. Nucleic Acids Research 36, e115.

Futreal, P. A., Coin, L., Marshall, M., Down, T., Hubbard, T., Wooster, R., Rahman, N. and Stratton, M. R. (2004). A census of human cancer genes. Nature Reviews Cancer 4, 177-183.

Graziano, F., Humar, B. and Guilfor, P. (2003). The role of the E-cadherin gene $(\mathrm{CDH} 1)$ in diffuse gastric cancer susceptibility: from the laboratory to clinical practice. Annals of Oncology 14, 1705-1713. 
Greenman, C., Stephens, P., Smith, R., Dalgliesh, G. L., Hunter, C., Bignell, G., Davies, H., Teague, J., Butler, A, Stevens, C., Edkins, S., O’Meara, S., Vastrik, I., Schmidt, E. E., Avis, T., Barthorpe, S., Bhamra, G., Buck, G., Choudhury, B., Clements, J., Cole, J., Dicks, E., Forbes, S., Gray, K., Halliday, K., Harrison, R., Hills, K., Hinton, J., Jenkinson, A., Jones, D., Menzies, A., Mironenko, T., Perry, J., Raine, K., Richardson, D., Shepherd, R., Small, A., Tofts, C., Varian, J., Webb, T., West, S., Widaa, S., Yates, A., Cahill, D. P., Louis, D.N., Goldstraw, P., Nicholson, A. G., Brasseur, F., Looijenga, L., Weber, B. L., Chiew, Y. E., DeFazio, A., Greaves, M. F., Green, A. R., Campbell, P., Birney, E., Easton, D. F., Chenevix-Trench, G., Tan, M. H., Khoo, S. K., Teh, B. T., Yuen, S. T., Leung, S. Y., Wooster, R., Futreal, P. A. and Stratton, M. R. (2007). Patterns of somatic mutation in human cancer genomes. Nature 446, 153-158.

Guo, X. and Wang, X. F. (2009). Signaling cross-talk between TGF- $\beta /$ BMP and other pathways. Cell Research 19, 71-88.

Hanahan, D. and Weinberg, R. A. (2011). Hallmarks of cancer: the next generation. Cell 144, 646-674.

Hartl, D. L. (2011). Chapter 13: molecular genetics of the cell cycle and cancer. In Essential Genetics (Edited by D. L. Hartlm), 5th edition, 431-462. Jones and Bartlett publishers, New Jersey.

Hearle, N., Schumacher, V., Menko, F. H., Olschwang, S., Boardman, L. A., Gille, J. J., Keller, J. J., Westerman, A. M., Scott, R. J., Lim, W., Trimbath, J. D., Giardiello, F. M., Gruber, S. B., Offerhaus, G. J., Rooij, F. W., Wilson, J. H., Hansmann, A., Möslein, G., Royer-Pokora, B., Vogel, T., Phillips, R. K., Spigelman, A. D. and Houlston, R. S. (2006). STK11 status and intussusception risk in Peutz-Jeghers syndrome. Journal of Medical Genetics 43, e41.

Herbst, R. S., Heymach, J. V. and Lippman, S. M. (2008). Molecular origins of cancer: lung cancer. New England Journal of Medicine 359, 1367-1380.

Hong, F., Breitling, R., McEntee, C. W., Wittner, B. S., Nemhauser, J. L. and Chory, J. (2006). RankProd: a bioconductor package for detecting differentially expressed genes in meta-analysis. Bioinformatics 22, 28252827.

Hsing, A. W., Tsao, L. and Devesa, S. S. (2000). International trends and patterns of prostate cancer incidence and mortality. International Journal of Cancer 1, 60-67. 
Imai, K. and Yamamoto, H. (2008). Carcinogenesis and microsatellite instability: the interrelationship between genetics and epigenetics. Carcinogenesis 29, 673-680.

Iacopetta, B. (2003). TP53 mutation in colorectal cancer. Human Mutation 21, 271-276.

Jančík, S., Drábek, J., Radzioch, D. and Hajdúch, M. (2010). Clinical relevance of KRAS in human cancers. Journal of Biomedicine and Biotechnology 150960, 1-13.

Jemal, A., Bray, F., Center, M. M., Ferlay, J., Ward, E. and Forman, D. (2011). Global cancer statistics. CA: A Cancer Journal for Clinicians 61, 69-90.

Jones, P. A. and Baylin, S. B. (2002). The fundamental role of epigenetic events in cancer. Nature Reviews Genetics 3, 415-428.

Jones, S., Zhang, X., Parsons, D.W., Lin, J. C., Leary, R. J., Angenendt, P., Mankoo, P., Carter, H., Kamiyama, H., Jimeno, A., Hong, S. M., Fu, B., Lin, M. T., Calhoun, E. S., Kamiyama, M., Walter, K., Nikolskaya, T., Nikolsky, Y., Hartigan, J., Smith, D. R., Hidalgo, M., Leach, S.D., Klein, A.P., Jaffee, E. M., Goggins, M., Maitra, A., Iacobuzio-Donahue, C., Eshleman, J. R., Kern, S. E., Hruban, R. H., Karchin, R., Papadopoulos, N., Parmigiani, G., Vogelstein, B., Velculescu, V. E. and Kinzler, K. W. (2008). Core signaling pathways in human pancreatic cancers revealed by global genomic analyses. Science 321, 1801-1806.

Juan, H. F. (2011). System Biology: Applications in Cancer-Related Research, 1st edition. Edited by H. F. Juan and H. C. Huang. World Scientific Publishing, New Jersey.

Kaminker, J. S., Zhang, Y., Waugh, A., Haverty, P. M., Peters, B., Sebisanovic, D., Stinson, J., Forrest, W. F., Bazan, J. F., Seshagiri, S. and Zhang, Z. (2007a). Distinguishing cancer-associated missense mutations from common polymorphisms. Cancer Research 67, 465-473.

Kaminker, J. S., Zhang, Y., Watanabe, C. and Zhang, Z. (2007b). CanPredict: a computational tool for predicting cancer-associated missense mutations. Nucleic Acids Research 35, W595-W598.

Klinz, F. J., Telentschak, S., Goldbrunner, R. and Addicks, K. (2011). Chapter 6: genetic diversity of glioblastoma multiforme: impact on future therapies. In Glioma - Exploring Its Biology and Practical Relevance (Edited by A. Ghosh), 103-130. InTech, New York. 
Knudso, A. G. (2001). Two genetic hits (more or less) to cancer. Nature Reviews Cancer 1, 157-162.

Kok, H. S., van Asselt, K. M., van der Schouw, Y. T., Peeters, P. H. M. and Wijmenga, C. (2005). Genetic studies to identify genes underlying menopausal age. Human Reproduction Update 11, 483-493.

Lacopetta, B. J., Soong, R., House, A. K. and Hamelin, R. (1999). Gastric carcinomas with microsatellite instability: clinical features and mutations to the TGF-beta type II receptor, IGFII receptor, and BAX genes. Journal of Pathology 187, 428-432.

Lag, R., Melbert, D., Krapcho, M., Mariotto, A., Miller, B. A., Feuer, E. J., Clegg, L., Horner, M. J., Howlader, N., Eisner, M. P. and Reichman, M. (2011). SEER Cancer Statistics Review, 1975-2004. Edited by B. K. Edwards. National Cancer Institute, Bethesda, Maryland.

Leav, I., Plescia, J., Goel, H. L., Li, J., Jiang, Z., Cohen, R. J., Languino, L. R. and Altieri, D. C. (2010). Cytoprotective mitochondrial chaperone TRAP1 as a novel molecular target in localized and metastatic prostate cancer. American Journal of Pathology 176, 393-401.

Lengauer, C., Kinzler, K. W. and Vogelstein, B. (1998). Genetic instabilities in human cancer. Nature 396, 643-649.

Lewin, B. (2004). Genes VIII. Oxford University Press, New York.

Lind, H., Zienolddiny, S., Ryberg, D., Skaug, V., Phillips, D. H. and Haugen, A. (2005). Interleukin 1 receptor antagonist gene polymorphism and risk of lung cancer: a possible interaction with polymorphisms in the interleukin 1 beta gene. Lung Cancer 50, 285-290.

Loeb, L. A., Bielas, J. H. and Beckman, R. A. (2008). Cancers exhibit a mutator phenotype: clinical implications. Cancer Research 68, 3551-3557.

Loriaux, M. M., Levine, R. L., Tyner, J. W., Fröhling, S., Scholl, C., Stoffregen, E. P., Wernig, G., Erickson, H., Eide, C. A., Berger, R., Bernard, O. A., Griffin, J. D., Stone, R. M., Lee, B., Meyerson, M., Heinrich, M. C., Deininger, M. W., Gilliland, D. G. and Druker, B. J. (2008). Highthroughput sequence analysis of the tyrosine kinome in acute myeloid leukemia. Blood 111, 4788-4796.

Lukusa, T. and Fryns, J. P. (2008). Human chromosome fragility. Biochimica et Biophysica Acta 1779, 3-16. 
Lynch, E. D., Ostermeyer, E. A., Lee, M. K., Arena, J. F., Ji, H., Dann, J., Swisshelm, K., Suchard, D., MacLeod, P. M., Kvinnsland, S., Gjertsen,. B. T., Heimdal, K., Lubs, H., Møller, P. and King, M. C. (1997). Inherited mutations in PTEN that are associated with breast cancer, cowden disease, and juvenile polyposis. American Journal of Human Genetics 61, 12541260.

Ma, P. C., Jagadeeswaran, R., Jagadeesh, S., Tretiakova, M. S., Nallasura, V., Fox, E. A., Hansen, M., Schaefer, E., Naoki, K., Lader, A., Richards, W., Sugarbaker, D., Husain, A. N., Christensen, J. G. and Salgia, R. (2005). Functional expression and mutations of c-Met and its therapeutic inhibition with SU11274 and small interfering RNA in non-small cell lung cancer. Cancer Research 65, 1479-1488.

Markowitz, S. D. and Bertagnolli, M. M. (2009). Molecular origins of cancer: molecular basis of colorectal cancer. New England Journal of Medicine 361, 2449-2460.

McDonald, M., Hertz, R. P. and Lowenthal, S. W. P. (2008). The burden of cancer in Asia. Pfizer Facts, 1-83.

Merlo, L. M., Pepper, J. W., Reid, B. J. and Maley, C. C. (2006). Cancer as an evolutionary and ecological process. Nature Reviews Cancer 6, 924-935.

Ng, P. C. and Henikoff, S. (2003). SIFT: predicting amino acid changes that affect protein function. Nucleic Acids Research 31, 3812-3814.

Nobili, S. Bruno, L., Landini I., Napoli, C., Bechi, P., Tonelli, F., Rubio, C.A. Mini, E. and Nesi, G. (2011). Genomic and genetic alterations influence the progression of gastric cancer. World Journal of Gastroenterology 17, 290-299.

Ottini, L., Falchetti, M., Saieva, C., De Marco, M., Masala, G., Zanna, I., Paglierani, M., Giannini, G., Gulino, A., Nesi, G., Mariani Costantini, R. and Palli, D. (2004). MRE11 expression is impaired in gastric cancer with microsatellite instability. Carcinogenesis 25, 2337-2343.

Palmieri, G., Palomba, G., Cossu, A., Pisano, M., Dedola, M. F., Sarobba, M. G., Farris, A., Olmeo, N., Contu, A., Pasca, A., Satta, M. P., Persico, I., Carboni, A. A., Cossu-Rocca, P., Contini, M., Mangion, J., Stratton, M. R. and Tanda, F. (2002). BRCA1 and BRCA2 germline mutations in Sardinian breast cancer families and their implications for genetic counseling. Annals of Oncology 13, 1899-1907. 
Park, J. Y., Jeon, H. S., Park, S. H., Park, T. I., Son, J. W., Kim, C. H., Park, J. H., Kim, I. S., Jung, T. H. and Jun, S. H. (2000). Microsatellite alteration in histologically normal lung tissue of patients with non-small cell lung cancer. Lung Cancer 30, 83-89.

Park, J. Y., Lee, S. Y., Jeon, H. S., Bae, N. C., Chae, S. C., Joo, S., Kim, C. H., Park, J. H., Kam,. S., Kim, I. S. and Jung, T. H. (2002). Polymorphism of the DNA repair gene XRCC1 and risk of primary lung cancer. Cancer Epidemiology Biomarkers \& Prevention 11, 23-27.

Park, J. Y., Park, J. M., Jang, J. S., Choi, J. E., Kim, K. M., Cha, S. I., Kim, C. H., Kang, Y. M., Lee, W. K., Kam, S., Park, R. W., Kim, I. S., Lee, J. T. and Jung, T. H. (2006). Caspase 9 promoter polymorphisms and risk of primary lung cancer. Human Molecular Genetics 15, 1963-1971.

Peifer, M., Fernández-Cuesta, L., Sos, M. L., George, J., Seidel, D., Kasper, L. H., Plenker, D., Leenders, F., Sun, R., Zander, T., Menon, R., Koker, M., Dahmen, I., Müller, C., Di Cerbo, V., Schildhaus, H. U., Altmüller, J., Baessmann, I., Becker, C., de Wilde, B., Vandesompele, J., Böhm, D., Ansén, S., Gabler, F., Wilkening, I., Heynck, S., Heuckmann, J. M., Lu, X., Carter, S. L., Cibulskis, K., Banerji, S., Getz, G., Park, K. S., Rauh, D., Grütter, C., Fischer, M., Pasqualucci, L., Wright, G., Wainer, Z., Russell, P., Petersen, I., Chen, Y., Stoelben, E., Ludwig, C., Schnabel, P., Hoffmann, H., Muley, T., Brockmann, M., Engel-Riedel, W., Muscarella, L. A., Fazio, V. M., Groen, H., Timens, W., Sietsma, H., Thunnissen, E., Smit, E., Heideman, D. A., Snijders, P. J., Cappuzzo, F., Ligorio, C., Damiani, S., Field, J., Solberg, S., Brustugun, O. T., Lund-Iversen, M., Sänger, J., Clement, J. H., Soltermann, A., Moch, H., Weder, W., Solomon, B., Soria, J. C., Validire, P., Besse, B., Brambilla, E., Brambilla, C., Lantuejoul, S., Lorimier, P., Schneider, P. M., Hallek, M., Pao, W., Meyerson, M., Sage, J., Shendure, J., Schneider, R., Büttner, R., Wolf, J., Nürnberg, P., Perner, S., Heukamp, L. C., Brindle, P. K., Haas, S. and Thomas, R. K. (2012). Integrative genome analyses identify key somatic driver mutations of small-cell lung cancer. Nature Genetics 44, 1104-1110.

Perneger, T. V. (1998). What's wrong with Bonferroni adjustments. BMJ 316, $1236-1238$

Redon, R., Ishikawa, S., Fitch, K. R., Feuk, L., Perry, G. H., Andrews, T. D., Fiegler, H., Shapero, M. H., Carson, A. R., Chen, W., Cho, E. K., Dallaire, S., Freeman, J. L., González, J. R., Gratacòs, M., Huang, J., Kalaitzopoulos, D., Komura, D., MacDonald, J. R., Marshall, C. R., Mei, R., Montgomery, L., Nishimura, K., Okamura, K., Shen, F., Somerville, 
M. J., Tchinda, J., Valsesia, A., Woodwark, C., Yang, F., Zhang, J., Zerjal, T., Zhang, J., Armengol, L., Conrad, D. F., Estivill, X., Tyler-Smith, C., Carter, N. P., Aburatani, H., Lee, C., Jones, K. W., Scherer, S. W. and Hurles, M. E. (2006). Global variation in copy number in the human genome. Nature 444, 444-454.

Samuels, Y. and Velculescu, V. E. (2004). Oncogenic mutations of PIK3CA in human cancers. Cell Cycle 3, 1221-1224.

Sánchez-Cespedes, M., Parrella, P., Esteller, M., Nomoto, S., Trink, B., Engles, J.M., Westra, W. H., Herman, J. G. and Sidransky, D. (2002). Inactivation of LKB1/STK11 is a common event in adenocarcinomas of the lung. Cancer Research 62, 3659-3662.

Sánchez-Pérez, I., García Alonso, P. and Belda Iniesta, C. (2009). Clinical impact of aneuploidy on gastric cancer patients. Clinical and Translational Oncology 11, 493-498.

Segditsas, S. and Tomlinson, I. (2006). Colorectal cancer and genetic alterations in the Wnt pathway. Oncogene 25, 7531-7537.

Senapati, S., Rachagani, S., Chaudhary, K., Johansson, S. L., Singh, R. K. and Batra, S. K. (2010). Overexpression of macrophage inhibitory cytokine-1 induces metastasis of human prostate cancer cells through the FAK-RhoA signaling pathway. Oncogene 9, 1293-1302.

Shigematsu, H., Takahashi, T., Nomura, M., Majmudar, K., Suzuki, M., Lee, H., Wistuba, I. I., Fong, K. M., Toyooka, S., Shimizu, N., Fujisawa, T., Minna, J. D. and Gazdar, A. F. (2005). Somatic mutations of the HER2 kinase domain in lung adenocarcinomas. Cancer Research 65, 1642-1646.

Simpson, A. J., Caballero, O. L. and Pena, S. D. (2001). Microsatellite instability as a tool for the classification of gastric cancer. Trends in Molecular Medicine 7, 76-80.

Sjöblom, T., Jones, S., Wood, L. D., Parsons, D. W., Lin, J., Barber, T. D., Mandelker, D., Leary, R. J., Ptak, J., Silliman, N., Szabo, S., Buckhaults, P., Farrell, C., Meeh, P., Markowitz, S. D., Willis, J., Dawson, D., Willson, J. K. V., Gazdar, A. F., Hartigan, J., Wu, L., Liu, C., Parmigiani, G., Park, B. H., Bachman, K. E., Papadopoulos, N., Vogelstein, B., Kinzler, K. W. and Velculescu, V. E. (2006). The consensus coding sequences of human breast and colorectal cancers. Science 314, 268-274. 
Soussi, T., Dehouche, K. and Béroud, C. (2000). p53 website and analysis of p53 gene mutations in human cancer: forging a link between epidemiology and carcinogenesis. Human Mutation 15, 105-113.

Steelman, L. S., Chappell, W. H., Abrams, S. L., Kempf, R. C., Long J., Laidler P., Mijatovic S., Maksimovic-Ivanic, D., Stivala, F., Mazzarino, M. C., Donia, M., Fagone, P., Malaponte, G., Nicoletti, F., Libra, M., Milella, M., Tafuri, A., Bonati, A., Bäsecke, J., Cocco, L., Evangelisti, C., Martelli, A. M., Montalto, G., Cervello, M. and McCubrey, J. A. (2011). Roles of the Raf/MEK/ERK and PI3K/PTEN/Akt/mTOR pathways in controlling growth and sensitivity to therapy-implications for cancer and aging. Aging 3, 192-222.

Stephens, P., Edkins, S., Davies, H., Greenman, C., Cox, C., Hunter, C., Bignell, G., Teague, J., Smith, R., Stevens, C., O'Meara, S., Parker, A., Tarpey, P., Avis, T., Barthorpe, A., Brackenbury, L., Buck, G., Butler, A., Clements, J., Cole, J., Dicks, E., Edwards, K., Forbes, S., Gorton, M., Gray, K., Halliday, K., Harrison, R., Hills, K., Hinton, J., Jones, D., Kosmidou, V., Laman, R., Lugg, R., Menzies, A., Perry, J., Petty, R., Raine, K., Shepherd, R., Small, A., Solomon, H., Stephens, Y., Tofts, C., Varian, J., Webb, A., West, S., Widaa, S., Yates, A., Brasseur, F., Cooper, C. S., Flanagan, A. M., Green, A., Knowles, M., Leung, S. Y., Looijenga, L. H. J., Malkowicz, B., Pierotti, M. A., The, B., Yuen, S. T., Nicholson, A. G., Lakhani, S., Easton, D. F., Weber, B. L., Stratton, M. R., Futreal, P. A. and Wooster, R. (2005). A screen of the complete protein kinase gene family identifies diverse patterns of somatic mutations in human breast cancer. Nature Genetics 37, 590-592.

Stephens, P., Hunter, C., Bignell, G., Edkins, S., Davies, H., Teague, J., Stevens, C., O'Meara, S., Smith, R., Parker, A., Barthorpe, A., Blow, M., Brackenbury, L., Butler, A., Clarke, O., Cole, J., Dicks, E., Dike, A., Drozd, A., Edwards, K., Forbes, S., Foster, R., Gray, K., Greenman, C., Halliday, K., Hills, K., Kosmidou, V., Lugg, R., Menzies, A., Perry, J., Petty, R., Raine, K., Ratford, L., Shepherd, R., Small, A., Stephens, Y., Tofts, C., Varian, J., West, S., Widaa, S., Yates, A., Brasseur, F., Cooper, C. S., Flanagan, A. M., Knowles, M., Leung, S. Y., Louis, D. N., Looijenga, L. H. J., Malkowicz, B., Pierotti, M. A., Teh, B., Chenevix-Trench, G., Weber, B. L., Yuen, S. T., Harris, G., Goldstraw, P., Nicholson, A. G., Futreal, P. A., Wooster, R. and Stratton, M. R. (2004). Lung cancer: intragenic ERBB2 kinase mutations in tumours. Nature 431, 525-526.

Straszewski-Chavez, S. L., Abrahams, V. M., Funai, E. F. and Mor, G. (2004). 
X-linked inhibitor of apoptosis (XIAP) confers human trophoblast cell resistance to Fas-mediated apoptosis. Molecular Human Reproduction 10, $33-41$.

Stratton, M. R., Campbell, P. J. and Futreal, P. A. (2009). The cancer genome. Nature 458, 719-724.

Subramanian, A., Tamayo, P., Mootha, V. K., Mukherjee, S., Ebert, B. L., Gillette, M. A., Paulovich, A., Pomeroy, S. L., Golub, T. R., Lander, E. S. and Mesirov, J. P. (2005). Gene set enrichment analysis: a knowledgebased approach for interpreting genome-wide expression profiles. PNAS, Proceedings of the National Academy of Sciences 102, 15545-15550.

Sugai, T., Habano, W., Jiao, Y. F., Suzuki, M., Takagane, A. and Nakamura, S. (2005). Analysis of genetic alterations associated with DNA diploidy, aneuploidy and multiploidy in gastric cancers. Oncology 68, 548-557.

te Velde, E. R. and Pearson, P. L. (2002). The variability of female reproductive ageing. Human Reproduction Update 8, 141-154.

TCGA (The Cancer Genome Atlas Research Network). (2008). Comprehensive genomic characterization defines human glioblastoma genes and core pathways. Nature 455, 1061-1068.

TCGA (The Cancer Genome Atlas Research Network). (2011). Integrated genomic analyses of ovarian carcinoma. Nature 474, 609-615.

IARC (The International Agency for Research on Cancer). (1980, 1986, 1987, 1994). Statistical Methods in Cancer Research I-IV. IARC Scientific Publications, Oxford University Press, New York.

ICGC (The International Cancer Genome Consortium). (2010). International network of cancer genome projects. Nature 464, 993-998.

Thomas, H. V., Reeves, G. K. and Key, T. J. (1997). Endogenous estrogen and postmenopausal breast cancer: a quantitative review. Cancer Causes Control 8, 922-928.

Tomasson, M. H., Xiang, Z., Walgren, R., Zhao, Y., Kasai, Y., Miner, T., Ries, R. E., Lubman, O., Fremont, D. H., McLellan, M. D., Payton, J. E., Westervelt, P., DiPersio, J. F., Link, D. C., Walter, M. J., Graubert, T. A., Watson, M., Baty, J., Heath, S., Shannon, W. D., Nagarajan, R., Bloomfield, C. D., Mardis, E. R., Wilson, R. K. and Ley, T. J. (2008). Somatic mutations and germline sequence variants in the expressed tyrosine 
kinase genes of patients with de novo acute myeloid leukemia. Blood 111, 4797-4808.

Torkamani, A. and Schork, N. J. (2007). Accurate prediction of deleterious protein kinase polymorphisms. Bioinformatics 23, 2918-2925.

Travis, W. D., Travis, L. B. and Devesa, S. S. (1995). Lung cancer. Cancer 75, 191-202.

Valverde, J. R., Alonso, J., Palacios, I. and Pestaña, A. (2005). RB1 gene mutation up-date, a meta-analysis based on 932 reported mutations available in a searchable database. BMC Genetics 6, 53 .

Verhaak, R. G., Hoadley, K. A., Purdom, E., Wang, V., Qi, Y., Wilkerson, M. D., Miller, C. R., Ding, L., Golub, T., Mesirov, J. P. Alexe, G., Lawrence, M., O’Kelly, M., Tamayo, P., Weir, B. A., Gabriel, S., Winckler, W., Gupta, S., Jakkula, L., Feiler, H. S., Hodgson, J. G., James, C. D., Sarkaria, J. N., Brennan, C., Kahn, A., Spellman, P. T., Wilson, R. K., Speed, T. P., Gray, J. W., Meyerson, M., Getz, G., Perou, C. M., Hayes, D. N., Cancer Genome Atlas Research Network. (2010). Integrated genomic analysis identifies clinically relevant subtypes of glioblastoma characterized by abnormalities in PDGFRA, IDH1, EGFR, and NF1. Cancer Cell 17, 98-110.

Vickie, L. V. and Saundra, S. B. (2010). Management of the patient with a genetic predisposition for breast cancer. In Management of Breast Diseases (Edited by I. Jatoi and M. Kaufmann), 551-568. Springer, New York.

Vogelstein, B., Fearon, E. R., Hamilton, S. R., Kern, S. E., Preisinger, A. C., Leppert, M., Nakamura, Y., White, R., Smits, A. M. and Bos, J. L. (1988). Genetic alterations during colorectal-tumor development. New England Journal of Medicine 319, 525-532.

Volm, M. and Koomägi, R. (2000). Hypoxia-inducible factor (HIF-1) and its relationship to apoptosis and proliferation in lung cancer. Anticancer Research 20, 1527-1533.

Wang, Z. Shen, D., Parsons, D. W., Bardelli, A., Sager, J., Szabo, S., Ptak, J., Silliman, N., Peters, B. A., van der, Heijden, M. S., Parmigiani, G., Yan, H., Wang, T. L., Riggins, G., Powell, S. M., Willson, J. K., Markowitz, S., Kinzler, K. W., Vogelstein, B. and Velculescu, V. E. (2004). Mutational analysis of the tyrosine phosphatome in colorectal cancers. Science 304, 1164-1166. 
Weinberg, R. A. (2007). The biology of cancer. In The Biology of Cancer (Edited by R. A Weinberg), 1st edition. Garland Science, New York.

Wenzlaff, A. S., Cote, M. L., Bock, C. H., Land, S. J., Santer, S. K., Schwartz, D. R. and Schwartz, A. G. (2005). CYP1A1 and CYP1B1 polymorphisms and risk of lung cancer among never smokers: a population-based study. Carcinogenesis 26, 2207-2212.

Wodarz, D. and Komarova, N. L. (2008). Computational Biology of Cancer: Lecture Notes and Mathematical Modeling, 3rd edition. Edited by N. J. Hackensack. World Scientific, New Jersey.

Wood, L. D., Parsons, D. W., Jones, S., Lin, J., Sjöblom, T., Leary, R. J., Shen, D., Boca, S. M., Barber, T., Ptak, J., Silliman, N., Szabo, S., Dezso, Z., Ustyanksky, V., Nikolskaya, T., Nikolsky, Y., Karchin, R., Wilson, P. A., Kaminker, J. S., Zhang, Z., Croshaw, R., Willis, J., Dawson, D., Shipitsin, M., Willson, J. K., Sukumar, S., Polyak, K., Park, B. H., Pethiyagoda, C. L., Pant, P. V., Ballinger, D. G., Sparks, A. B., Hartigan, J., Smith, D. R., Suh, E., Papadopoulos, N., Buckhaults, P., Markowitz, S. D., Parmigiani, G., Kinzler, K. W., Velculescu, V. E. and Vogelstein, B. (2007). The genomic landscapes of human breast and colorectal cancers. Science 318, 1108-1113.

Yager, J. D. and Davidson, N. E. (2006). Estrogen carcinogenesis in breast cancer. New England Journal of Medicine 354, 270-282.

Yeang, C. H., McCormick, F. and Levine, A. (2008). Combinatorial patterns of somatic gene mutations in cancer. FASEB Journal 22, 2605-2622.

Yue, P., Melamud, E. and Moult, J. (2006). JSNPs3D: candidate gene and SNP selection for association studies. BMC Bioinformatics 7, 166.

Zienolddiny, S., Ryberg, D., Arab, MO., Skaug, V. and Haugen, A. (2001). Loss of heterozygosity is related to p53 mutations and smoking in lung cancer. British Journal of Cancer 84, 226-231.

Zou, J. X., Guo, L., Revenko, A. S., Tepper, C. G., Gemo, A. T., Kung, H. J. and Chen, H. W. (2009). Androgen-induced coactivator ANCCA mediates specific androgen receptor signaling in prostate cancer. Cancer Research 69, 3339-3346. 
Nardnisa Sintupisut

Institute of Statistical Science

Academia Sinica

28 Academia Road, Section 2, Nankang, Taipei 115, Taiwan

nardnisa@gmail.com

Chen-Hsiang Yeang

Institute of Statistical Science

Academia Sinica

28 Academia Road, Section 2, Nankang, Taipei 115, Taiwan

chyeang@stat.sinica.edu.tw 